Marquette University

e-Publications@Marquette

$10-1-2012$

\title{
International R\&D Transfer and Technical Efficiency: Evidence from Panel Study Using Stochastic Frontier Analysis
}

Miao Wang

Marquette University, grace.wang@marquette.edu

M. C. Sunny Wong

University of San Francisco

Accepted version. World Development, Vol. 40, No. 10 (October 2012): 1982-1998. DOI. Published under Creative Commons license Attribution-NonCommercial-NoDerivatives 4.0 International. 


\title{
International R\&D Transfer and Technical Efficiency: Evidence from Panel Study using Stochastic Frontier Analysis
}

\author{
Miao Wang \\ Department of Economics, Marquette University \\ Milwaukee, WI \\ M.C. Sunny Wong \\ Department of Economics, University of San Francisco \\ San Francisco, CA
}

\begin{abstract}
Summary. - We study the effect of foreign R\&D transferred through imports and FDI on domestic technical efficiency using stochastic frontier analysis. Unbalanced panel results from a 77-country sample over 1986-2007 show that FDI- and imports-transferred foreign R\&D have a significant impact on domestic country's technical efficiency. Furthermore, we observe a complementarity between FDI-transferred R\&D and domestic human capital. In other words, the domestic country needs to obtain a threshold level of human capital to benefit from FDI-transferred R\&D. Other macro conditions such as infrastructure, political stability, and urbanization also help to improve the technical efficiency of a country.
\end{abstract}

Keywords - R\&D, FDI, Trade, Technical Efficiency 
NOT THE PUBLISHED VERSION; this is the author's final, peer-reviewed manuscript. The published version may be accessed by following the link in the citation at the bottom of the page.

\section{Acknowledgements}

We would like to thank Brian Brush, Hongying Chen, Joseph Daniels, Farrokh Nourzad, Hong Zhuang, three anonymous referees as well as the participants at the 66th International Atlantic Economic Conference 2008 for their helpful comments and suggestions on earlier versions of this paper. This research is partially supported by the College of Business Administration Center for Global and Economic Studies at Marquette University.

\section{Introduction}

The development of endogenous growth theory has put international technology diffusion in a central position in the recent literature on economic growth. Endogenous growth theories emphasize that technology improvement and human capital accumulation are the main engines of economic growth (Aghion \& Howitt, 1992; Barro \& Sala-i-Martin, 1997; Romer, 1990). Macro-level studies show that world research and development (R\&D) activities tend to be concentrated in developed OECD countries. For instance, the U.S., Japan, the U.K., France, Germany, Italy, and Canada took up 92\% of OECD R\&D expenditure in 1991 (Coe, Helpman, \& Hoffmaister, 1997). In 2007, the U.S., Japan, Germany, France, and the U.K. accounted for approximately $60 \%$ of world total R\&D expenditure (UNESCO, 2009). Knowledge creation and technological innovations in these developed countries tend to promote their productivity growth. Yet, with increasing globalization, open economies constantly interact with each other in both product and capital markets. Knowledge created in a particular country generally transcends its national boundary and R\&D spillovers will not be confined within one country. In other words, technological innovations in certain countries can be transferred to foreign economies through various channels such as foreign direct investment (FDI) and international trade, and the international diffusion of knowledge and innovations may be a major reason of total factor productivity (TFP) growth in many economies.

A large body of theoretical and empirical research has examined the impact of foreign R\&D on domestic productivity and its importance has been recognized by many. Seminal studies include Grossman and Helpman (1991), Coe and Helpman (1995), Coe, et al. (1997), and van Pottelsberghe de la Potterie and Lichtenberg (2001). ${ }^{1}$ For instance, Coe and Helpman (1995) find a significant contribution of international

World Development, Vol 40, No. 10 (October 2012): pg. 1982-1998. DOI. This article is @ Elsevier and permission has been granted for this version to appear in e-Publications@Marquette. Elsevier does not grant permission for this article to be further copied/distributed or hosted elsewhere without the express permission from Elsevier. 
R\&D spillovers to the TFP growth of 22 developed countries. Focusing on imports as a channel of R\&D spillovers, Coe, et al. (1997) estimate that a one-percent increase in foreign $R \& D$ raises the productivity growth in less developed countries (LDCs) by $0.06 \%$, other things held constant.

However, as argued by Henry, Kneller, and Milner (2009), by mainly focusing on technology transfer and productivity, the literature might be providing only a partial explanation of the cross-country productivity differences since countries are likely to differ in the efficiency with which they use technologies. It is well acknowledged that a country's productivity as well as its economic growth performance depends on "the extent of technology transfers from the leading countries and the efficiency with which they are absorbed and diffused" (Blomstrom, Lipsey \& Zejan, 1994, p.10) (see also Eaton \& Kortum, 1996; Kneller \& Stevens, 2006). Consequently, having access to technology transfer from foreign countries is not necessarily equivalent to productivity growth. It is also critical to understand whether the technology transfer can be utilized efficiently in a domestic country.

In this study, we employ a stochastic frontier model to explore the extent to which foreign R\&D transfer contribute to domestic technical efficiency. Our study contributes to the literature in two respects. First, productivity growth in general consists of two components: (i) technical efficiency improvement, and (ii) technical change. Technical efficiency is defined as a country's ability to obtain maximum output from a given vector of inputs, so technical efficiency improvement refers to the movements toward the production frontier. On the other hand, a technical change leads to an outward shift of the production frontier. Growth-accounting methodology provides an empirical framework to study sources of economic growth (Solow,1957). It breaks down the growth rate of total output in an economy into two sources: an increase in the amount of factors of production used, and an increase in productivity -- "technical change", measured as a residual often referred to as the "Solow residual" (Kendrick, 1961; Jorgenson \& Griliches, 1967). A potential caveat is that previous analyses of TFP based on the Solow residual calculation generally do not distinguish between technical efficiency change and

World Development, Vol 40, No. 10 (October 2012): pg. 1982-1998. DOI. This article is @ Elsevier and permission has been granted for this version to appear in e-Publications@Marquette. Elsevier does not grant permission for this article to be further copied/distributed or hosted elsewhere without the express permission from Elsevier. 
technical change. Typically, all countries are assumed to be perfectly efficient and operate on their production frontier as Mastromarco and Ghosh (2009) note, "the use of the residual as technical change is reasonable only if all countries are producing on their Frontier" (p491) (see also Kumbhakar \& Lovell, 2000).

As production efficiency varies across countries, we revisit studies of international R\&D spillovers (Coe \& Helpman, 1995; Coe, et al., 1997) to investigate the impact of international R\&D on the domestic country's technical efficiency. We take the approach of stochastic frontier analysis suggested by Battese and Coelli (1995), which estimates the production frontier and describes the deviation of a country's production from its best practice for panel data. ${ }^{2}$ The major advantage of using the stochastic frontier model is that we can relax the assumption that individual countries always operate on their production frontier. By applying the stochastic frontier model, we can understand technical efficiency variation across countries and also analyze factors that affect technical efficiency change.

Second, previous research adopting the stochastic frontier framework primarily focuses on the role of trade or FDI itself as a determinant of technical efficiency (Kneller \& Stevens, 2006; Mastromarco, 2008; Nourzad, 2008; Wijeweera, Villano, \& Dollery, 2010). Few have focused on the role of trade and FDI as conduits for international R\&D transfer with exceptions of Henry, et al. (2009) and Mastromarco and Ghosh (2009). Henry, et al. (2009) study imports as a channel of transferring international R\&D into 57 less developed countries (LDCs) over the time period of 1970-1998. The authors find that trade is an important channel for international technology diffusion, which increases the individual country's ability to move toward its production frontier. The results are echoed in Mastromarco and Ghosh (2009). Based on panel data from 57 LDCs from 19602000, Mastromarco and Ghosh find that inward FDI, imports, and foreign R\&D transferred through imports all have a positive effect on a domestic country's technical efficiency.

In our paper, we consider both FDI and trade as conduits for R\&D transfer and estimate their effects on domestic technical efficiency. While Henry, et al. (2009) and Mastromarco and Ghosh

World Development, Vol 40, No. 10 (October 2012): pg. 1982-1998. DOI. This article is @ Elsevier and permission has been granted for this version to appear in e-Publications@Marquette. Elsevier does not grant permission for this article to be further copied/distributed or hosted elsewhere without the express permission from Elsevier. 
(2009) investigate imports as the only channel of international R\&D spillovers, such spillovers can occur through inward FDI as well. World imports indeed have a larger value than world FDI inflows. But compared to imports, capital flows by many measures have grown much faster. The annual average growth of world FDI inflows, more than doubling the growth rate of world imports, was $23.6 \%$ over the period of $1986-1990,20 \%$ over $1991-1995$, and $30.1 \%$ over $2005-$ 2007. Studying the impact of international R\&D diffusion on TFP, Hejazi and Safrian (1999) point out that excluding FDI may result in "attributing to trade spillovers that are actually occurring through FDI" (p.492). The authors find that FDI is an important channel of transferring foreign knowledge stock, which has a positive impact on domestic country's TFP (see also Xu \& Wang, 2000). Furthermore, a recent study by Keller and Yeaple (2009) investigates the effect of the international technology spillovers on the growth of TFP in the U.S. manufacturing industry. Keller and Yeaple argue that productivity spillovers can come from either FDI or imports. Using firm level data over 1987-1996, they find that the spillover effect of inward FDI is significantly stronger than the spillover effect of imports on domestic firms' TFP growth (Wang \& Blomström, 1992; Rodriguez-Clare, 1996; Brambilla, Hale, \& Long, 2009).

Following Coe and Helpman (1995) and Coe, et al. (1997), we take 20 developed OECD countries (OECD20) as the source of international R\&D. We employ data from 77 countries over the time period of 1986- 2007. Complementing Henry, et al. (2009) and Mastromarco and Ghosh (2009) on technical efficiency, our paper is the first to study both inward FDI and imports as channels for foreign R\&D transfer systematically. Comparing the impact of inward FDItransferred $R \& D$ to the impact of imports-transferred $R \& D$, we can also draw inferences on, for example, which one has a larger influence on technical efficiency.

To preview our results, we find that foreign R\&D transferred through FDI and imports has a positive impact on domestic technical efficiency. Our findings also suggest a complementarity between FDItransferred foreign R\&D and domestic human capital. For countries with higher level of human capital, the positive effect of FDItransferred foreign R\&D on domestic technical efficiency will be larger.

World Development, Vol 40, No. 10 (October 2012): pg. 1982-1998. DOI. This article is @ Elsevier and permission has been granted for this version to appear in e-Publications@Marquette. Elsevier does not grant permission for this article to be further copied/distributed or hosted elsewhere without the express permission from Elsevier. 
This finding is consistent with the argument that the level of human capital is positively related to a country's capacity to absorb new knowledge and technology (Kneller \& Stevens, 2006). Other factors such as infrastructure, political stability, and urbanization also help to improve the technical efficiency of a country.

In terms of the level of efficiency, OECD20 are among the most efficient countries in the world with an average efficiency score of 0.913 (maximum value of one, which indicates a country is operating on its production frontier). Among LDCs in our sample, Asian economies obtain the highest level of efficiency at 0.816 over the period of 1986-2007, while sub-Saharan countries tend to fall in the group of least efficient economies with an average efficiency score of 0.576 .

We estimate that foreign R\&D transferred through imports and FDI together account for $9.97 \%$ of the world technical efficiency. This means that the average level of technical efficiency would have been 9.97\% lower were it not for the positive effect of foreign R\&D transfer. Inward FDI-transferred foreign R\&D plays an important role in improving a country's technical efficiency. Specifically, our results suggest that the potential improvement in world average technical efficiency is $3.1 \%$ with an increase in inward FDI-transferred R\&D. On the other hand, an increase in imports-transferred R\&D leads to a $3 \%$ improvement in world technical efficiency.

Our paper is organized as follows: Section 2 outlines the stochastic frontier model; section 3 presents empirical specification and data. We discuss empirical results in section 4 and offer conclusions in section 5 .

\section{Stochastic Frontier Model General Framework}

We analyze countries' technical efficiency based on the approach of the stochastic frontier technique (Aigner, et al., 1977). The stochastic frontier model estimates the maximum output level for a country based on a set of production inputs. The difference between a country's maximum output and its actual output is defined as the

World Development, Vol 40, No. 10 (October 2012): pg. 1982-1998. DOI. This article is @ Elsevier and permission has been granted for this version to appear in e-Publications@Marquette. Elsevier does not grant permission for this article to be further copied/distributed or hosted elsewhere without the express permission from Elsevier. 
technical inefficiency. The general specification of a frontier model is as follows:

$$
\ln Y_{i t}=1 n X_{i t} \beta+\left(v_{i t}-u_{i t}\right),
$$

where subscripts $i$ and $t$ are country and year indexes, respectively; $Y$ represents the real output of a country, $X$ is a vector of production inputs, and $\beta$ is the corresponding vector of coefficients. The error term $\left(v_{i t}-u_{i t}\right)$ in equation (1) consists of two components: a random error, $v_{i t}$, and the technical inefficiency, $u_{i t}$. The random error term, $v_{i t}$, is assumed to have an iid normal distribution, i.e., $v_{i t} \sim N\left(0, \sigma_{v}^{2}\right)$; the technical inefficiency term, $u_{i t}$, is defined by the truncation (at zero) of the normal distribution with mean, $\mu_{i t}$, and variance, $\sigma_{u}^{2}$. In addition, the inefficiency effects are assumed to be independently distributed for different countries and years.

The mean of the distribution can be represented as a linear function of certain determinants, included in the vector $Z$ (Battese \& Coelli, 1995):

$$
\mu_{i t}=\mathrm{Z}_{i t} \delta
$$

Kumbhakar, Ghosh, and McGuckin (1991) propose a singlestage maximum likelihood procedure to estimate equations (1) and (2). Battese and Coelli (1995) extend and modify this procedure for the use of panel data. In this context, technical efficiency (TE) is defined as the ratio of actual output to the maximum output level and can be calculated as: ${ }^{3}$

$$
T E=E\left[\exp \left(-u_{i t}\right) \mid \varepsilon_{i t}\right]
$$

World Development, Vol 40, No. 10 (October 2012): pg. 1982-1998. DOI. This article is (C) Elsevier and permission has been granted for this version to appear in e-Publications@Marquette. Elsevier does not grant permission for this article to be further copied/distributed or hosted elsewhere without the express permission from Elsevier. 


\section{Empirical Specification and Data}

\section{(a) Production function}

We model the production function (1) with the more flexible translog functional form. The translog functional form is preferred to the Cobb-Douglas functional form for frontier analysis given that the translog function does not impose constant elasticity of substitution (Kneller \& Stevens, 2003; Kumbhakar \& Wang, 2005). The log linear form of our translog production function gives:

$$
\begin{aligned}
\ln Y_{i t}=\beta_{0}+ & \beta_{K} \ln K_{i t}+\beta_{L} \ln L_{i t}+\beta_{H} \ln H_{i t}+\frac{1}{2} \beta_{K K}\left(\ln K_{i t}\right)^{2} \\
& +\frac{1}{2} \beta_{L L}\left(\ln L_{i t}\right)^{2}+\frac{1}{2} \beta_{H H}\left(\ln H_{i t}\right)^{2}+\beta_{K L}\left(\ln K_{i t} \times \ln L_{i t}\right) \\
& +\beta_{K H}\left(\ln K_{i t} \times \ln H_{i t}\right)+\beta_{L H}\left(\ln L_{i t} \times \ln H_{i t}\right)+\beta_{Y r} \text { Year } \\
& +\beta_{Y r s q} \text { Year }{ }^{2}+\beta_{Y r K}\left(\text { Year } \times \ln K_{i t}\right) \\
& +\beta_{Y r L}\left(\text { Year } \times \ln L_{i t}\right)+\beta_{Y r H}\left(\text { Year } \times \ln H_{i t}\right) \\
& +\beta_{R} \text { Regions }+\left(v_{i t}-u_{i t}\right)
\end{aligned}
$$

where $K, L$, and $H$ represent physical capital, labor force, and human capital, respectively; Regions are regional dummy variables representing Asia, Latin America and the Caribbean (LAC), Middle East and North Africa (MENA), and sub-Saharan Africa (SSA). ${ }^{4}$ We include time trend (Year) and the time-squared variables to allow for nonmonotonic technical change. The interaction variables between trend and production inputs are also included in equation (4) for the possibility of non-neutral technical change.

We measure output by real GDP in millions of constant 2000 dollars. Data on GDP and labor force come from the World Development Indicators (WDI) published by the World Bank. There are no readily available data on physical capital stock, and we estimate physical capital stock using the perpetual inventory method commonly adopted in the literature:

World Development, Vol 40, No. 10 (October 2012): pg. 1982-1998. DOI. This article is @ Elsevier and permission has been granted for this version to appear in e-Publications@Marquette. Elsevier does not grant permission for this article to be further copied/distributed or hosted elsewhere without the express permission from Elsevier. 


$$
K_{i 0}=\frac{\text { investment }_{i 0}}{g_{i}+d}
$$

and

$$
K_{i t}=(1-d) K_{i t-1}+\text { investment }_{i t},
$$

where $K_{i 0}$ represents the initial physical capital stock for country $i$; investment $_{i 0}$ is the initial domestic investment in country $i ; g_{i}$ is a weighted average of the world and country $i$ 's GDP growth rate over the first decade of our sample period. Following Easterly and Levine (2001), the world average GDP growth rate is given the weight of 0.75 and country $i$ 's average GDP growth rate is given the weight of 0.25 to calculate $g_{i} ; d$ represents the depreciation rate of physical capital and is assumed to take the value of 0.07.5 Gross fixed capital formation data used to calculate physical capital stock are also collected from the WDI.

Our measure of human capital comes from Barro and Lee (2000) and is the average years of secondary schooling in the total population over the age of 15 . The schooling data are reported every five years $(1960,1965,1970, \ldots)$. As a result, schooling for 1985 reported in Barro and Lee is used in our sample for human capital over 1985-1989; schooling reported for 1990 is used in our sample for 1990-1994; and so on. Since the data are available up to 2000, linear interpolation is used for schooling data over 2004-2007. In addition, we also employ an alternative measure of human capital, secondary school enrollment rate, for robustness check. The enrollment rate is provided by the United Nations Educational, Scientific, and Cultural Organization (UNESCO). ${ }^{6}$

\section{(b) Inefficiency function}

Variables included in the average technical inefficiency function represent a country's infrastructure, openness, urbanization, political stability, and knowledge stock transferred by foreign investment and imports. The average technical inefficiency function is represented as follows:

World Development, Vol 40, No. 10 (October 2012): pg. 1982-1998. DOI. This article is @ Elsevier and permission has been granted for this version to appear in e-Publications@Marquette. Elsevier does not grant permission for this article to be further copied/distributed or hosted elsewhere without the express permission from Elsevier. 
NOT THE PUBLISHED VERSION; this is the author's final, peer-reviewed manuscript. The published version may be accessed by following the link in the citation at the bottom of the page.

$$
\begin{aligned}
\mu_{i t}=Z_{i t} \delta=\delta_{0} & +\sum_{n=1}^{8} \delta_{n} z_{n, i t}=\delta_{0}+\delta_{1} \ln I N F R A_{i t}+\delta_{2} O P E N_{i t}+\delta_{3} U R B_{i t} \\
& +\delta_{4} \ln P S_{i t}+\delta_{5} \ln R D_{i t}^{F D I}+\delta_{6} \ln R D_{i t}^{M}+\delta_{7}\left(\ln R D_{i t}^{F D I} \times \ln H_{i t}\right) \\
& +\delta_{8}\left(\ln R D_{i t}^{M} \times \ln H_{i t}\right)
\end{aligned}
$$

where $\left(\ln R D_{i t}^{F D I}\right)$ is the log value international R\&D transferred by inward FDI and $\left(\ln R D_{i t}^{M}\right)$ is the log of international R\&D transferred by imports into country $i .^{7}$

Previous literature has discussed the important role of domestic absorptive capacity in adopting new technologies from foreign countries (Borensztein, et al., 1998; Cohen \& Levinthal, 1989; Findlay, 1978; Glass \& Saggi, 1998). Findlay (1978) theoretically studies the relationship between relative backwardness and the speed of adopting new technologies and spillover benefits from multinational corporations. Findlay concludes that the positive effect of FDI spillovers is stronger the larger the technology gap between home and host countries. However, more recent studies tend to argue differently. For example, Glass and Saggi (1998) take the technology gap as an indicator of the host's absorptive capacity. The authors suggest that when the gap is large, the host country might not have a sufficient level of human capital to benefit from the technology transferred by FDI. Similarly, Borensztein, et al. (1998) argue that inward FDI will promote a host country's economic growth only when that host country achieves a certain absorptive capacity, measured by a threshold level of average years of secondary schooling. In other words, there exists a complementarity between inward FDI and a host country's human capital in promoting that host country's economic growth. To explore whether a similar complementarity exists in our model and the extent to which human capital affects a country's adoption of foreign $R \& D$, we include the two interactive terms in the regression, $\ln R D_{i t}^{F D I} \times \ln H_{i t}$ and $\ln R D_{i t}^{M} \times \ln H_{i t}$. If a country needs to achieve a certain level of human capital to benefit from foreign R\&D in terms of reducing inefficiency, we should observe negative and significant coefficients on the interactive terms. World R\&D activities tend to be concentrated in developed OECD countries (Coe \& Helpman, 1995; Coe, et al., 1997). As mentioned previously, approximately $60 \%$ of world total R\&D expenditure (UNESCO, 2009) in 2007 came from

World Development, Vol 40, No. 10 (October 2012): pg. 1982-1998. DOI. This article is @ Elsevier and permission has been granted for this version to appear in e-Publications@Marquette. Elsevier does not grant permission for this article to be further copied/distributed or hosted elsewhere without the express permission from Elsevier. 
the U.S., Japan, Germany, France, and the U.K. Following Coe and Helpman (1995) and Coe, et al. (1997), we take 20 developed OECD countries (OECD20) as the source of international knowledge stock, which can be transferred to country $i$ through FDI from OECD20 $\left(R D_{i}^{F D I}\right)$ and through imports in country $i$ from OECD20 $\left(R D_{i}^{M}\right) \cdot{ }^{8}$ All other non-OECD20 countries in our sample are categorized as LDCs. For each of the LDCs in our sample, $R D^{F D I}$ is the bilateral-inward FDIshare weighted sum of OECD20's domestic R\&D capital stock and $R D^{M}$ is the bilateral-imports-share weighted sum of OECD20's domestic R\&D stock. For any one of the OECD20 countries, $R D^{F D I}$ and $R D^{M}$ represent the bilateral-inward FDI-share weighted sum and the bilateral-imports-share weighted sum of the other 19 OECD countries' domestic R\&D capital stock, respectively. In particular, for any year $t$ :

$$
\begin{gathered}
R D_{i t}^{F D I}=\sum_{j \in\{O E C D 20\}} \frac{F D I_{j i t}}{F D I_{j t}} \times R D_{j t}, \text { for } j \neq i \\
R D_{i t}^{M}=\sum_{j \in\{O E C D 20\}} \frac{M_{j i t}}{E_{j t}} \times R D_{j t}, \text { for } j \neq i
\end{gathered}
$$

where $R D_{j t}$ is the level of domestic R\&D capital stock in country $j$, for $j \in\{O E C D 20\}$, and $i \in\{O E C D 20, L D C s\}$. In equation (8), the term $F D I_{j i}$ represents inward FDI in country $i$ from country $j$, and $F D I_{j}$ represents total FDI outflows from country $j$ to all $i$ s. In equation (9), $M_{J I}$ represents imports in country $i$ from country $j$ and $E_{j}$ is the total exports from country $j$ to all $i \mathrm{~s} .{ }^{9}$

To calculate the real value of domestic R\&D capital stock in each of the OECD20 countries, we employ data on real gross domestic R\&D expenditure, which is used as a proxy for annual R\&D investment. Then a perpetual inventory method similar to the one used for constructing physical capital stock is applied (equations (5) and (6)) to estimate the R\&D capital stock. ${ }^{10}$ We obtain data on annual bilateral FDI from OECD International Direct Investment Database. Trade data

World Development, Vol 40, No. 10 (October 2012): pg. 1982-1998. DOI. This article is @ Elsevier and permission has been granted for this version to appear in e-Publications@Marquette. Elsevier does not grant permission for this article to be further copied/distributed or hosted elsewhere without the express permission from Elsevier. 
are from the OECD Monthly Statistics of International Trade Database. Real gross domestic R\&D expenditure in OECD20 is from the OECD Science and Technology Statistics.

Figure 1 represents our calculated foreign R\&D transferred through inward FDI and imports for LDC regions in our sample over 1986-2007. ${ }^{11}$ On average, Asian economies received the largest value of international knowledge stock transferred through inward FDI and imports from OECD20. Latin America and the Caribbean (LAC) and Middle East and North Africa (MENA) had comparable levels of international R\&D transferred through different channels. Countries in sub-Saharan Africa (SSA) received the smallest amount of foreign R\&D among all LDCs. For example, the foreign R\&D stock transferred into Asia was $6100 \%$ larger than that into SSA through FDI, and $3900 \%$ larger than that into SSA through imports. R\&D transferred into LAC was $354 \%$ and $256 \%$ larger than that into SSA through FDI and imports, respectively. Similarly, R\&D transferred into MENA through FDI was $285 \%$ larger than that in SSA, and $245 \%$ larger than that in SSA through imports. Furthermore, Asian countries experienced the most stable increase in foreign R\&D transferred through inward FDI. The foreign knowledge stock transferred through FDI rose in other LDC regions in 1986-2007 as well, but fluctuated quite considerably, especially in MENA and SSA. In contrast, the knowledge stock transferred through imports into LDCs was much more stable. Asia and LAC had shown a stronger growth in foreign R\&D transferred through imports than MENA and SSA. MENA and SSA illustrated very similar dynamic patterns in terms of knowledge stock transferred through imports.

\section{[FIGURE 1 ABOUT HERE]}

The significance of infrastructure (INFRA) in the process of economic development has long been recognized. An adequate and reliable supply of infrastructure (e.g., infrastructure associated with communication and transportation) facilitates mobility and efficient allocation of inputs as well as final products, reduces transaction costs, and improves productivity (Roller \& Waverman, 2001). In addition, access to phones, power, and paved roads provides individuals with improved choice and can lead to a higher living standard. A number of

World Development, Vol 40, No. 10 (October 2012): pg. 1982-1998. DOI. This article is @ Elsevier and permission has been granted for this version to appear in e-Publications@Marquette. Elsevier does not grant permission for this article to be further copied/distributed or hosted elsewhere without the express permission from Elsevier. 
studies (Fedderke, Perkins, \& Luiz, 2006; Um, Straub, \& Vellutini, 2009) have illustrated the significant impact of infrastructure on economic growth and productivity. Infrastructure in our paper is proxied by the number of cell phone and land-line phone subscriptions per 100 people in a country (Ding, Haynes, \& Liu, 2008). We expect better infrastructure to promote technical efficiency.

While economic theory is fairly clear on the effect of infrastructure, the effect of openness of a country (OPEN) on technical inefficiency can be rather uncertain. On the one hand, openness of a country allows dissemination of knowledge in the economy, encourages competition, and promotes economic growth (Young, 1991; Dollar \& Kraay, 2004). On the other hand, Sachs and Warner (1999) point out that trade liberalization can have a long-term negative impact on a country's development if it leads to specialization in extractive sectors (Rodriguez \& Rodrik, 1999). In our study, we include a measure of openness, which is the sum of imports and exports as a share of GDP. The potential impact of openness on efficiency is ambiguous.

Urbanization is an important factor that can affect technical efficiency through several channels. But it has long been omitted from studies on economic performance. Jayasuriya and Wodon (2005) argue that "with the presence of universities, research centers, and many firms, cities thrive... facilitating spillovers" (p.122). In addition, Adams (2001) and Quigley (1998) point out cities help to maintain personal contacts and also provide a better match between skills and needs. We include as a measure of urbanization (URB) in our regressions the share of a country's population living in urban areas. We expect that an increase in urbanization will decrease technical inefficiency.

The last variable included in the inefficiency function is the political stability of a country $(P S)$. Better institutions and political stability help to secure property rights and reduce information costs and in turn help to promote technical efficiency (Klein \& Luu, 2003). Countries with poor institutional quality tend to exhibit worse growth performance (Rodrik, 1999). We employ the political risk index from

World Development, Vol 40, No. 10 (October 2012): pg. 1982-1998. DOI. This article is @ Elsevier and permission has been granted for this version to appear in e-Publications@Marquette. Elsevier does not grant permission for this article to be further copied/distributed or hosted elsewhere without the express permission from Elsevier. 
the International Country Risk Guide to measure a country's institutional and political stability. This index is a composite score from individual rankings of 12 components and ranges from zero (very risky) to 100 (very stable). ${ }^{12}$ We expect that an improvement in political stability will reduce inefficiency in a country.

Our data on infrastructure, openness, and urbanization are collected from WDI. The International Country Risk Guide is published by the Political Risk Service Group, Inc. We provide the summary statistics for our sample in Table 1.

[TABLE 1 HERE]

\section{Empirical Results}

Empirical results are provided in Table 2. We report five regressions for robustness checks. These five models are different in terms of R\&D depreciation rates, measures of human capital, and whether we treat human capital as a factor of production or a productivity-enhancing factor. We start with model 1 in which human capital (years of schooling) is taken as a factor of production and R\&D is assumed to depreciate at $5 \%$. In model 2 , we change the R\&D depreciation rate to $10 \%$ (Kneller \& Stevens, 2006; Mastromarco \& Ghosh, 2009). Models 3-5 all have 10\% R\&D depreciation rates. In Model 3, human capital is measured by the secondary school enrollment rate (Enroll) (Skidmore \& Toya, 2002). In model 4, we treat human capital as a productivity enhancing factor instead of a factor of production (Tallman \& Wang, 1994). In model 5, we control for potential endogeneity problem in the inefficiency function. For example, a more efficient country might attract more FDI, hence more FDI-transferred R\&D. To address this endogeneity concern, we use lagged variables concerning FDI- and import-transferred R\&D, which are predetermined, instead of contemporaneous R\&D transfers in model $5 .{ }^{13}$

Table 2 is divided into three panels. Panel A shows results for the production function and panel $B$ includes results for the technical inefficiency function. Note that in panel B we are estimating an inefficiency function, so a negative coefficient on a variable indicates

World Development, Vol 40, No. 10 (October 2012): pg. 1982-1998. DOI. This article is @ Elsevier and permission has been granted for this version to appear in e-Publications@Marquette. Elsevier does not grant permission for this article to be further copied/distributed or hosted elsewhere without the express permission from Elsevier. 
that an increase in the value of this variable will decrease inefficiency, or increase efficiency. In panel $C$, we report results of four likelihood ratio (LR) tests.

\section{[TABLE 2 HERE]}

As shown in Table 2, all five models provide similar qualitative results. For the purpose of brevity, our future empirical discussions will be based solely on results from model $2 .^{14}$

We first compare the Cobb-Douglas functional form with the translog form. The LR test indicates that the null hypothesis of the Cobb-Douglas functional form can be rejected at the $1 \%$ level. Given the specification of the translog function, the Cobb-Douglas is not an adequate representation of the data. In addition, empirical results also indicate non-neutral technical change over time. The coefficient on the interaction between time and capital is in general positively significant and the coefficient on the interaction between time and labor negative. Theoretically, our results imply that technical change has been capital saving and labor using. The isoquant in the production process is shifting inwards at a faster rate over time in the capital-intensive part of the input set (Coelli, Rao, O'Donnell, \& Battese, 2005).

We define $\gamma=\sigma_{u}^{2} / \sigma^{2}$, where $\sigma^{2}=\sigma_{u}^{2} / \sigma_{v}^{2}$ (Battese \& Coelli, 1995). ${ }^{15}$ The traditional ordinary least squares (OLS) method will generate consistent estimates only when the inefficiency effects do not exist. A likelihood-ratio test can be applied with a null hypothesis of $H_{0}: \gamma=\delta_{0}=\delta_{1}=\cdots=0$. If the null hypothesis is true, the test statistic has approximately a chi-square (or a mixed chi-square) distribution. Rejecting this null hypothesis suggests that technical inefficiency is present in the model and the maximum likelihood method is preferred to the traditional OLS.

The null hypothesis of no technical inefficiency is rejected at the $1 \%$ level in all regressions in Table 2 . Given the specification of the stochastic frontier model that is estimated, we cannot conclude that the technical inefficiency effects do not exist. According to the value of $Y$ (model 2), $90.4 \%$ of the variations in $\sigma^{2}$ can be accounted for by technical inefficiency. In addition, the likelihood ratio test on whether

World Development, Vol 40, No. 10 (October 2012): pg. 1982-1998. DOI. This article is @ Elsevier and permission has been granted for this version to appear in e-Publications@Marquette. Elsevier does not grant permission for this article to be further copied/distributed or hosted elsewhere without the express permission from Elsevier. 
the inefficiency is a function of our $\mathrm{Z}$ factors indicates that the null hypothesis can be rejected at the $1 \%$ level, suggesting that variables included in the technical inefficiency function explain the sources of inefficiency. Furthermore, a significant $\gamma$ also tells us that the maximum likelihood estimation technique is preferred to OLS.

Estimated coefficients in the translog function do not directly represent the elasticity of output with respect to different inputs. As a result, we calculate the elasticity as:

$$
\begin{gathered}
E_{x}=\frac{\partial \ln Y}{\partial \ln x}=\beta_{x}+\beta_{x^{2}} \ln x+\beta_{x w} \ln w+ \\
\beta_{t x} t, \text { for } x, w \in\{K, L, H\}, \text { and } x \neq w
\end{gathered}
$$

The average elasticity of output with respect to physical capital $\left(E_{k}\right)$ is 0.76 , the average elasticity with respect to labor $\left(E_{L}\right)$ is 0.18 , and the elasticity of output with respect to human capital $\left(E_{H}\right)$ is 0.15 . On average, our results suggest that output is more sensitive to a change in physical capital than a change in labor and human capital. These results are consistent with findings in Miller and Upadhyay (2000). Miller and Upadhyay study the effect of trade openness and human capital on total factor productivity. They find that $E_{k}$ is higher than $E_{L}$ using a sample including both developed and developing economies (see also, Koop et al., 1999, and Senjadij, 2000). Figure 2 displays box plots of output elasticity with respect to individual inputs at different points of the distribution over different regions. For regional elasticities, the estimated $E_{k}$ values in our study are within the range of those in Henry et al. (2009) and Senhadji (2000). ${ }^{16}$

\section{[FIGURE 2 HERE]}

One implication that emerges from our inefficiency function results is the importance of infrastructure, urbanization, and political stability in affecting the domestic country's technical efficiency. Infrastructure, urbanization, and political stability all have significantly negative coefficients, indicating that these factors have positive effects on technical efficiency. For example, the estimated coefficient on

World Development, Vol 40, No. 10 (October 2012): pg. 1982-1998. DOI. This article is (C) Elsevier and permission has been granted for this version to appear in e-Publications@Marquette. Elsevier does not grant permission for this article to be further copied/distributed or hosted elsewhere without the express permission from Elsevier. 
infrastructure suggests that a $1 \%$ increase in cell phone and land-line phone subscriptions decreases a country's technical inefficiency by $0.114 \%$, holding other things constant. Similarly, a $1 \%$ increase in the urbanization rate decreases the country's inefficiency by $0.45 \%$ and a one unit increase in the log value of political stability index decreases the country's inefficiency by $0.23 \%$, ceteris paribus. In other words, increasing urbanization and political stability along with an improvement in infrastructure lead to higher technical efficiency. The coefficient on the openness measure is positive and significant in all regressions, indicating that trade openness actually increases technical inefficiency. We do not have an a priori expectation for the coefficient on openness given the mixed evidence in the literature. Our results are consistent with conclusions of Sachs and Warner (1999), and Rodriguez and Rodrik (1999).

The coefficient on the international R\&D transferred through imports $\left(\ln R D^{M}\right)$ is negative and significant at the $1 \%$ level, which implies that international R\&D diffusion through imports helps improve a country's technical efficiency and confirms findings in Henry, et al. (2009) and Mastromarco and Ghosh (2009). The estimated coefficient on inward FDI-transferred foreign R\&D ( $\ln R D^{F D I}$ ) is negative and significant at the $5 \%$ level, suggesting that FDI is also an important channel of international R\&D diffusion and helps individual countries to move closer to their production frontiers.

The positive effect of foreign R\&D on efficiency is robust across different regions. We plot the estimated technical efficiency for individual countries against their FDI-transferred R\&D and importtransferred $R \& D$ by regions in Figure 3. International $R \& D$ transfers are positively associated with the level of technical efficiency in the developed OECD20 group as well as in all LDC regions in our sample (Asia, LAC, MENA, and SSA). Figure 3 also shows that the marginal effect of FDI- and import-transferred R\&D may be the smallest in the OECD20 group, which could be caused by diminishing marginal product of foreign $R \& D$.

[FIGURE 3 HERE]

World Development, Vol 40, No. 10 (October 2012): pg. 1982-1998. DOI. This article is @ Elsevier and permission has been granted for this version to appear in e-Publications@Marquette. Elsevier does not grant permission for this article to be further copied/distributed or hosted elsewhere without the express permission from Elsevier. 
The interaction between $\ln R D^{F D I}$ and human capital is negative and significant at the $1 \%$ level, while the coefficient on the interactive term, $\ln R D^{M} \times \ln H$, is positive. These results suggest that FDItransferred foreign R\&D will further improve the host country's technical efficiency if the host country achieves a higher level of human capital. Consequently, continued government efforts in increasing the level of human capital and focusing on investment in secondary education will strengthen the beneficial effect of foreign R\&D transfer on domestic efficiency. These results are consistent with Borensztein, et al. (1998). Similar results are also obtained by Li and Liu (2005) and, at the industry level, by Girma and Gorg (2007), who find that an absorptive capacity is more important for a country to benefit from FDI than from international trade.

We present average efficiency scores for individual countries in the Appendix (Table A). In our sample, the estimated average level of technical efficiency across all countries is 0.78 , implying a mean technical inefficiency of $0.25 .{ }^{17}$ If the log value of inward FDItransferred foreign R\&D rises by one unit, the technical inefficiency will change by $-0.0127-0.021 \times \ln H$ units, depending on the level of human capital in individual countries. In terms of the impact of foreign $R \& D$ transferred through imports, a one unit increase in the log value of import-transferred foreign R\&D changes inefficiency by $-0.0138-$ $0.034 \times \ln H$ units, other things constant. In figure 4, we present box plots of the impact of FDI- and imports-transferred foreign R\&D on inefficiency for countries in our sample. It appears that importtransferred foreign R\&D has a larger impact in general on decreasing inefficiency (an average of -0.13) than FDI-transferred foreign R\&D (an average of - 0.02).

[Figure 4 Here]

\section{(a) Regional efficiency}

On average, world technical efficiency rose by $15.8 \%$ from 0.734 in 1986 to 0.85 in 2007 . The U.K. was the most efficient country in the world with an average level of technical efficiency at 0.98 over 1986-2007. The technical efficiency level in LDCs improved on average

World Development, Vol 40, No. 10 (October 2012): pg. 1982-1998. DOI. This article is @ Elsevier and permission has been granted for this version to appear in e-Publications@Marquette. Elsevier does not grant permission for this article to be further copied/distributed or hosted elsewhere without the express permission from Elsevier. 
from 0.665 in 1986 to 0.832 in 2007 , representing a $25.1 \%$ increase. There exist considerable differences across LDCs regions as shown in Figure 5. Asian countries operate at a higher efficiency level than other LDC groups. Obtaining an average efficiency score of 0.82 over the period of 1986-2007, Asian economies are $7.2 \%$ more efficient than countries in LAC, $2.15 \%$ more efficient than MENA economies, and $41.5 \%$ more efficient than sub-Saharan African countries.

\section{[Figure 5 Here]}

It is worth emphasizing that Asia, LAC, MENA, and sub-Saharan Africa experienced very different dynamics in technical efficiency change. The efficiency score in Asia rose consistently over 1990-1996. It plunged in 1997 and reached a trough in 1998, which might be due to the negative impact of the Asian financial crisis in 1997 on the macroeconomy. But the level of technical efficiency in Asia soon recovered and began rising again in 1999.

In contrast, LAC endured a long span of stagnant efficiency from 1986 to the early 2000s. This stagnation of efficiency for almost two decades in LAC could be explained by its unstable macro environment. In the 1980 s and 1990s, LAC suffered from 36 severe banking/balance of payments crises. The inflation in LAC was at an average rate of $176.9 \%$ in the 1980 s and $49.5 \%$ in the 1990 s and the growth of productivity in both time periods in LAC was negative (Fraga, 2004).

The increase in the level of technical efficiency is also evident for MENA economies. With the exception of 1986-1991, countries in MENA are on a path of fast improvement in efficiency. As pointed out by Yousef (2004), MENA countries experienced a drastic decrease in physical capital accumulations in the 1980 s, which was caused by a decline in public revenue. But by the early 1990s, debt levels and inflation rates in MENA were brought under control. In addition, "governments also began a gradual transition to structural adjustment - a move strongly supported by international financial institutions and Western governments - including privatization of state-owned enterprises, trade liberalization, deregulation and strengthening the institutional foundations for a market-led economy" (Yousef, 2004, p. 99). The level of technical efficiency in sub-Saharan Africa fluctuated

World Development, Vol 40, No. 10 (October 2012): pg. 1982-1998. DOI. This article is @ Elsevier and permission has been granted for this version to appear in e-Publications@Marquette. Elsevier does not grant permission for this article to be further copied/distributed or hosted elsewhere without the express permission from Elsevier. 
over the period of 1986-1995 without an evident increase. But starting the second half of the 1990s, we observe a consistent upward trend in technical efficiency in sub-Saharan Africa.

Large variations in individual countries' performance within each region are quite evident as well. Table 3 presents the level of technical efficiency in different regions in five periods 1986-1989, 1990-1994, 1995-1999, 2000-2004, and 2005-2007 as well as our entire sample span of 1986-2007. We also report the efficiency scores of the 10 most efficient LDCs and the 10 least efficient LDCs in Table 4. Over our sample period, Latin America (Argentina, Brazil, Chile, Mexico, Uruguay) and Asia (Hong Kong, India, Singapore) dominate the list of the most efficient LDCs, while sub-Saharan African countries account for the majority of the least efficient countries. As illustrated in Table 3, although the average efficiency score in sub-Saharan Africa was around 0.58 , South Africa, the most efficient country in subSaharan Africa, achieved a level of efficiency above 0.9 in all five periods. On the other hand, Malawi and Togo are in the group of least efficient countries in sub-Saharan Africa with a score of 0.38 or lower. In other words, over 1986-2007, the most efficient country in subSaharan Africa was $165.5 \%$ more efficient than the least efficient country in the same region. This indeed is not a unique phenomenon in sub-Saharan Africa. In Latin America, Argentina and Uruguay were able to achieve a technical efficiency level above 0.95 , comparable to the OECD20 group. In contrast, the efficiency score for Guyana varied between 0.23 and 0.35 . The average level of technical efficiency in Uruguay (0.946) was $222 \%$ higher than the average level of technical efficiency in Guyana (0.294) over our entire sample period. Similar patterns also exist in Asia and MENA, but the difference between the most and the least efficient economies in Asia and MENA is not as dramatic as in Latin America and sub-Saharan Africa. For example, Hong Kong (0.941), the most efficient economy in Asia, was on average $76.6 \%$ more efficient than Sri Lanka (0.53), the least efficient economy in Asia. Egypt (0.86) as the most efficient country in MENA was $22.9 \%$ more efficient than Syria $(0.7)$, the least efficient country in the region.

\section{[TABLES 3, 4 HERE]}

World Development, Vol 40, No. 10 (October 2012): pg. 1982-1998. DOI. This article is @ Elsevier and permission has been granted for this version to appear in e-Publications@Marquette. Elsevier does not grant permission for this article to be further copied/distributed or hosted elsewhere without the express permission from Elsevier. 


\section{(b) Contributions of foreign R\&D to efficiency}

We provide, in this section, estimations of the contribution of foreign R\&D transferred through FDI and imports to technical efficiency in Tables 5 and 6 . Table 5 presents the overall contribution of R\&D transferred through different channels to the current level of technical efficiency as in Henry, et al. (2009). Table 6 presents the potential efficiency ratio based on calculations proposed by Coelli, Perelman, \& Romano, 1999).

The technical efficiency score (TE) is calculated as (Battese \& Coelli, 1995; Coelli, et al., 1999):

$$
\begin{gathered}
T E_{i t}=E\left[\exp \left(-u_{i t}\right) \mid \varepsilon_{i t}\right]=\left[\exp \left(-\mu_{i t}+\frac{1}{2} \sigma_{*}^{2}\right)\right] \times\{[1- \\
\left.\left.\Phi\left(\sigma_{*}-\frac{\mu_{i t}}{\sigma_{*}}\right)\right] /\left[1-\Phi\left(-\frac{\mu_{i t}}{\sigma_{*}}\right)\right]\right\}
\end{gathered}
$$

where $\Phi(\cdot)$ denotes the cumulative distribution function of the standard normal variable and:

$$
\begin{gathered}
\mu_{i t}=(1-\gamma)\left(\delta_{0}+\sum_{n=1}^{8} \delta_{n} Z_{n, i t}\right)-\gamma \varepsilon_{i t}, \sigma_{*}^{2}=\gamma(1-\gamma) \sigma^{2}, \text { and } \gamma= \\
\sigma_{u}^{2} /\left(\sigma_{u}^{2}+\sigma_{v}^{2}\right),
\end{gathered}
$$

where $\left[z_{1}, \cdots, z_{8}\right]=$ $\left\{\ln I N F R A_{i t}, O P E N_{i t}, U R B_{i t}, \ln P S_{i t}, \ln R D_{i t}^{F D I}, \ln R D_{i t}^{M}, \ln R D_{i t}^{F D I} \times\right.$ $\left.\ln H_{i t}, \ln R D_{i t}^{M} \times \ln H_{i t}\right\}$.

In Table 5, we present the percentage of current technical efficiency that is accounted for by foreign R\&D transfer, following Henry, et al. (2009). In this case, we calculate an upper limit and a lower limit of the contribution of foreign R\&D. The $\delta_{0}+\sum_{n=1}^{8} \delta_{n} Z_{n, i t}$ in equation (12) is replaced by $\min \left(\delta_{0}+\sum_{n=1}^{4} \delta_{n} z_{n, i t}\right)$ for the 
lower limit of the contribution of foreign R\&D transfer to efficiency score, and by $\max \left(\delta_{0}+\sum_{n=1}^{4} \delta_{n} Z_{n, i t}\right)$ for the upper limit. The contribution of foreign R\&D reported in Table 5 is an average of the upper and lower limits.

Over the period of 1986-2007, the average contribution of foreign R\&D transferred through inward FDI and imports to efficiency across all countries is estimated to be $9.97 \%$. This indicates that for a country with an average level of technical efficiency of 0.85 , its efficiency score would have dropped to about 0.72 if it did not receive any international R\&D through FDI and imports.

At the regional/group level, the effect of foreign R\&D appears to be the strongest in OECD20 countries, with an average contribution of foreign R\&D transfer to domestic technical efficiency at $12.18 \%$. Among LDCs, the average effect of foreign R\&D to efficiency is the strongest in Asia and MENA at around $10.3 \%$, followed by $9.77 \%$ in LAC. The contribution of foreign R\&D to technical efficiency is the weakest in sub-Saharan Africa, with foreign R\&D accounting for $6.65 \%$ of the current level of technical efficiency. For instance, the average level of technical efficiency in Asia over 1986-2007 was 0.82 and 0.58 in sub-Saharan Africa. Our results suggest that efficiency scores in Asia and sub-Saharan Africa would have dropped to 0.736 and 0.542 , respectively, if these two regions did not receive any foreign $R \& D$ through FDI and imports.

[TABLE 5 HERE]

An alternative measure of the contribution of foreign R\&D to efficiency, the "net technical efficiency", is suggested by Coelli, Perelman, and Romano (1999). While the calculation based on Henry, et al. (2009) illustrates the technical efficiency score if a country did not receive any foreign $R \& D$ transfer (it can be thought as a "backward" comparison with its status quo), Coelli, et al. (1999) provide a "forward" comparison by showing the potential domestic technical efficiency if a country received more foreign R\&D. We construct the net technical efficiency by replacing $\sum_{n=5}^{8} \delta_{n} Z_{n, i t}$ with $\min \left(\sum_{n=5}^{8} \delta_{n} Z_{n, i t}\right)$ in (12) and recalculating the efficiency 
scores. These adjusted predictions (or the "net technical efficiency") are predictions of efficiency scores when all countries face identical foreign $R \& D$ transfer conditions (i.e. the most favorable foreign $R \& D$ transfer condition). The difference between the net and the actual technical efficiency scores can be interpreted as the potential improvement in country $i$ 's level of efficiency if country $i$ 's foreign R\&D transfer through inward FDI and imports increases.

Table 6 reports the net technical efficiency (panel A) and the ratio of net technical efficiency to the actual level of technical efficiency across different regions (panel B), which we refer to as the potential efficiency ratio (PER). Panel $C$ in Table 6 presents the potential efficiency ratio for foreign $R \& D$ transferred through inward FDI and Panel $D$ the potential efficiency ratio for foreign R\&D transferred through imports.

The average potential efficiency ratio over our entire sample period is 1.035 for all countries, 1.011 for OECD20, and 1.059 for nonOECD20 groups. If foreign R\&D transferred through both inward FDI and imports in different countries improves to the most favorable condition in our sample (i.e. the level of foreign $R \& D$ received by the U.S.), the average technical efficiency score would rise by $1.1 \%$ in OECD20 countries, and by $5.9 \%$ in non-OECD20 countries. As OECD20 countries are among the most efficient countries and already receive a large value of foreign R\&D, their "room" for improvement in efficiency by receiving more foreign $R \& D$ is small (1.1\%). However, LDCs can experience a considerable improvement in efficiency with increasing foreign $R \& D$. If $L D C s$ receive the same level of foreign $R \& D$ transferred through FDI and imports as in the U.S., their level of technical efficiency would increase, on average, by about $5.9 \%$.

These results have important policy implications for developing countries. LDCs may have limited resources devoted to their domestic R\&D capital stock. However, governments of LDCs can employ preferential policies to encourage international trade and to attract foreign investment. With R\&D diffusion through imports and capital inflows, LDCs may benefit substantially in terms of efficiency improvement. Our results also provide information on how much

World Development, Vol 40, No. 10 (October 2012): pg. 1982-1998. DOI. This article is @ Elsevier and permission has been granted for this version to appear in e-Publications@Marquette. Elsevier does not grant permission for this article to be further copied/distributed or hosted elsewhere without the express permission from Elsevier. 
NOT THE PUBLISHED VERSION; this is the author's final, peer-reviewed manuscript. The published version may be accessed by following the link in the citation at the bottom of the page.

improvement LDCs could achieve if they further liberalize their goods and capital markets.

The average potential gain in efficiency over 1986-2007 was $6.9 \%$ for sub-Saharan countries, $4.4 \%$ for MENA economies, 3.9\% for LAC countries, and $2.3 \%$ for Asian economies. For example, countries in LAC had an average efficiency score of 0.76 over 1986-2007. Our estimates suggest that if foreign $R \& D$ received in $L A C$ increased to the level of foreign $R \& D$ received in the U.S., then the average technical efficiency in Latin America would have risen to 0.79. Similarly, if the foreign $R \& D$ received by countries in sub-Saharan Africa were the same as the foreign R\&D received by the U.S., the average level of technical efficiency in SSA would have improved to 0.62 from 0.58 .

[TABLE 6 HERE]

Given that international R\&D transfer through both imports and FDI inflows can improve the country's efficiency, how should governments evaluate different policy options toward trade and FDI? Again, this question is of particular importance to LDCs as they have more room for efficiency improvement by receiving more foreign R\&D. In order to answer this question, it is necessary to further look at contributions of FDI-transferred R\&D and imports-transferred R\&D separately.

As shown in the lower panels of Table 6, the average potential efficiency ratio is 1.031 with improvement in foreign R\&D transferred through inward FDI, and 1.03 with improvement in foreign R\&D transferred through imports over the period of 1986-2007.

At the regional level for all LDCs, the average potential efficiency ratio ranges between 1.03 in Asia and 1.059 in sub-Saharan Africa based on improvements in FDI-transferred R\&D, and ranges between 1.02 in Asia and 1.05 in sub-Saharan Africa based on improvements in imports-transferred R\&D. Take the estimated potential efficiency ratios in 1995-1999 as an example. The actual efficiency scores in Asia, LAC, MENA, and sub-Saharan Africa in 19951999 are $0.817,0.762,0.804$, and 0.563 , respectively. The potential efficiency ratio for FDI transferred R\&D in 1995-1999 is 1.033 for Asia,

World Development, Vol 40, No. 10 (October 2012): pg. 1982-1998. DOI. This article is @ Elsevier and permission has been granted for this version to appear in e-Publications@Marquette. Elsevier does not grant permission for this article to be further copied/distributed or hosted elsewhere without the express permission from Elsevier. 
NOT THE PUBLISHED VERSION; this is the author's final, peer-reviewed manuscript. The published version may be accessed by following the link in the citation at the bottom of the page.

1.034 for LAC, 1.044 for MENA, and 1.059 for sub-Saharan Africa. These results suggest that holding everything else constant, if the FDItransferred foreign $R \& D$ received in these regions rose to the amount received by the U.S., then the level of technical efficiency would have increased to 0.844 in Asia, 0.788 in LAC, 0.839 in MENA, and 0.596 in sub-Saharan Africa. The potential efficiency ratios due to improvement in imports-transferred $R \& D$ in 1995-1999 are 1.024, 1.031, 1.041, and 1.056 in Asia, LAC, MENA, and sub-Saharan Africa, respectively. Consequently, this indicates that holding everything else constant, if imports-transferred R\&D in these LDCs could reach the level of imports-transferred R\&D in the U.S., the level of technical efficiency would have risen to 0.837 in Asia, 0.786 in LAC, 0.837 in MENA, and 0.595 in sub-Saharan Africa.

Focusing on individual non-OECD20 countries, we find that the largest potential improvements in efficiency due to an increase in FDItransferred foreign R\&D are between 6-7\% in Mozambique, Malawi, Mali, and Papua New Guinea and the smallest potential improvements in efficiency are between $0.5-1 \%$ in Korea, Hong Kong, Argentina, and Mexico. In terms of the potential improvements in efficiency due to an increase in imports-transferred foreign $R \& D$, the strongest effects are between 7-9\% for Gambia, Congo, and Sri Lanka. The smallest effects are in Mexico and Brazil at 0.1-0.3\%.

Our results show that the potential improvements in efficiency due to imports-transferred foreign and inward FDI-transferred foreign $R \& D$ are comparable. These positive impacts are especially important to low- and middle-income countries.

\section{Concluding Remarks}

The dissemination of knowledge allows countries to benefit from foreign R\&D. Our paper contributes to the literature by focusing on both FDI and imports as conduits of international technology spillovers and studying to what extent FDI- and imports-transferred foreign R\&D affect domestic technical efficiency. Using stochastic frontier analysis and panel data from both LDCs and developed OECD countries over the period of 1986-2007, we find that cross-country differences in technical efficiency can be explained by differences in foreign R\&D

World Development, Vol 40, No. 10 (October 2012): pg. 1982-1998. DOI. This article is @ Elsevier and permission has been granted for this version to appear in e-Publications@Marquette. Elsevier does not grant permission for this article to be further copied/distributed or hosted elsewhere without the express permission from Elsevier. 
spillovers, domestic country's absorptive capacity, and other macro conditions.

Our results confirm that imports are an important channel for international R\&D spillovers and also highlight the significant impact of inward FDI-transferred foreign R\&D on domestic technical efficiency. Foreign R\&D transferred through both inward FDI and imports on average account for $9.97 \%$ of the world technical efficiency over 1986 2007 , with the largest contribution in OECD20 at $12.18 \%$ and the smallest contribution in sub-Saharan Africa at $6.65 \%$. In addition, we show that with an increase in the FDI-transferred R\&D (to the most favorable level in our sample), the world current level of technical efficiency would improve by $3.1 \%$. Similarly, with an increase in imports-transferred foreign R\&D, the world current level of technical efficiency would improve by $3 \%$.

There exist substantive variations in the level of efficiency across countries in our sample. Not surprisingly, developed OECD countries on average achieve the highest level of technical efficiency at 0.91. Among LDCs, Asian economies (0.82) typically obtain a higher level of efficiency than other LDCs. Sub-Saharan African countries consistently are among the least efficient economies with an average technical efficiency score of 0.58 over our sample period.

Our results are meaningful to policymakers, especially policymakers in LDCs. As LDCs may not have adequate domestic resources to promote $R \& D$ stock accumulation, our study suggests that adopting preferential policies to promote trade and capital flows and increase the access to foreign $R \& D$ can be extremely important to the improvement in efficiency for LDCs.

Efficiency also depends on other factors such as infrastructure and political stability. Improvements in infrastructure and political stability as well as increases in urbanization all help improve technical efficiency in a country. 
NOT THE PUBLISHED VERSION; this is the author's final, peer-reviewed manuscript. The published version may be accessed by following the link in the citation at the bottom of the page.

\section{Endnotes}

${ }^{1}$ See Keller (2004) for a detailed survey of the international R\&D spillovers literature.

2 The stochastic frontier model is initially used to study technical efficiency of individual firms and later generalized to macroeconomic research (Aigner, Lovell, \& Schmidt, 1977; Battese \& Coelli, 1988; Nourzad, 2008; Meeusen \& van den Broeck, 1977).

${ }^{3}$ For further technical details of the stochastic frontier model, we refer readers to Battese \& Coelli $(1988,1995)$.

${ }^{4}$ We follow the theoretical framework of production function in Borensztein, De Gregoio, and Lee (1998), in which human capital is considered as a factor of production. For the purpose of robustness check, we also estimate the model where human capital is assumed to be a laborenhancing factor (Tallman \& Wang, 1994). Detailed estimated results are presented in Section 4.

${ }^{5}$ Values of physical capital stock were also calculated using $d=0.1$ and the empirical results are qualitatively similar to the results with $d=0.07$ for physical capital.

${ }^{6}$ When using enrollment rate as the measure of human capital, our sample includes 86 countries.

7 In regressions, we take $\left(\ln R D_{i t}^{F D I}+1\right)$ and $\left(\ln R D_{i t}^{M}+1\right)$.

${ }^{8}$ OECD20 includes Australia, Austria, Belgium, Canada, Denmark, Finland, France, Germany, Ireland, Italy, Japan, Netherlands, New Zealand, Norway, Portugal, Spain, Sweden, Switzerland, the U.K., and the U.S.

${ }^{9}$ For example, if in year $t, 5 \%$ of total FDI outflows from the U.S. went to Thailand, then $F D I_{U S, \text { Thailand }} / F D I_{U S}=0.05$. In this case, we can calculate the knowledge stock transferred into Thailand from the U.S. through FDI as $0.05 \times R D_{U S}$.

${ }^{10}$ In terms of the depreciation rate for R\&D capital stock, Bureau of Labor Statistics (BLS) considers that R\&D in applied research is depreciated at a rate of $10 \%$, and $R \& D$ stock in basic research is not depreciated at all (BLS, 1989). Coe and Helpman (1995) and Coe, et al. (1997) calculate R\&D stock based on a $5 \%$ depreciation rate. We report in our paper results based on depreciation rates of both $5 \%$ and $10 \%$ for R\&D capital stock.

${ }^{11}$ Figure 1 is constructed based on a $10 \%$ depreciation rate for R\&D stock.

12 The 12 individual components include government stability, socioeconomic conditions, investment profile, internal conflict, external conflict, corruption, military in politics, religion in politics, law and order, ethnic tensions, democratic accountability, and bureaucracy quality.

${ }^{13}$ A few existing studies discuss the endogeneity concern in frontier models, but mainly focus on $\mathrm{X}$-variable (variables in the production function)

World Development, Vol 40, No. 10 (October 2012): pg. 1982-1998. DOI. This article is @ Elsevier and permission has been granted for this version to appear in e-Publications@Marquette. Elsevier does not grant permission for this article to be further copied/distributed or hosted elsewhere without the express permission from Elsevier. 
NOT THE PUBLISHED VERSION; this is the author's final, peer-reviewed manuscript. The published version may be accessed by following the link in the citation at the bottom of the page.

endogeneity (Guan, Kumbhakar, Myers, \& Oude-Lansink, 2009). Potential endogenous inefficiency factors have not been discussed in the literature. Basic stochastic frontier models as well as most software packages for this type of analysis cannot account for endogenous variables, either in the production function or in the inefficiency function. Fully addressing the potential endogeneity problem in the inefficiency function is beyond the scope of this paper. We use in the inefficiency function lagged values of FDI transferredand imports transferred- R\&D instead of contemporaneous values to control for endogeneity.

${ }^{14}$ Post-estimation discussions based on other models are available upon request.

${ }^{15} \gamma$ is bounded between zero and one.

16 Senhadji (2000) points out that the size of $E_{k}$ in developing countries relative to $E_{k}$ in developed countries can be ambiguous although the literature suggests that $E_{k}$ in developing countries is larger than that in developed countries. $E_{k}$ is calculated as the product of marginal product of capital $(\partial Y \partial K)$ and the capital-output ratio $(K / Y)$. Senhadji argues the marginal product of capital (MPK) is high in developing countries, but their capital-output ratio is low, which leads to uncertainty in the value of $E_{k}$. Similarly, the high capital-output ratio in developed countries can be offset by their low value of MPK due to diminishing returns and therefore the size of $E_{k}$ can be uncertain in developed countries as well. In Koop et al. (1999), the authors focus on 17 OECD countries and they observe that countries with very high $K / L$ ratio may have very low output elasticity with respect to physical capital. In some cases, the value of $E_{K}$ can be up to 0.9 and much higher than the value of $E_{L}$.

17 The level inefficiency is $-\ln (0.78)=0.25$.

\section{References}

Adams, J. (2001). Comparative localization of academic and industrial spillovers. NBER Working Paper No. 8292, National Bureau of Economic Research.

Aghion, P., \& Howitt, P. (1992). A model of growth through creative destruction. Econometrica, 60(2), 323-351.

Aigner, D. J., Lovell, C. A. K., \& Schmidt, P. (1977). Formulation and estimation of stochastic frontier droduction function models. Journal of Econometric, 6(1), 21-37.

Barro, R. J., \& Sala-i-Martin, X. (1997). Technological diffusion, convergence, and growth. Journal of Economic Growth, 2(1), 1-26.

World Development, Vol 40, No. 10 (October 2012): pg. 1982-1998. DOI. This article is @ Elsevier and permission has been granted for this version to appear in e-Publications@Marquette. Elsevier does not grant permission for this article to be further copied/distributed or hosted elsewhere without the express permission from Elsevier. 
Barro, R. J., \& Lee, J.-W. (2000). International data on educational attainment updates and implications. NBER Working Paper No. 7911, National Bureau of Economic Research.

Battese, G., \& Coelli, T. (1988). Prediction of firm-level technical efficiencies: with a generalized frontier production function and panel data. Journal of Econometrics, 38(3), 387-399.

Battese, G., \& Coelli, T. (1995). A model for technical inefficiency effects in a stochastic frontier production function for panel data. Empirical Economics, 20(2), 325-332.

Blomstrom, M., Lipsey, R., \& Zejan, M. (1994). What explains growth in developing countries? In Baumol, W., Nelson, R., Wolff, E., (Eds.), Convergence of productivity: Cross-national studies and historical evidence. Oxford and New York: Oxford University Press.

Bureau of Labor Statistics. (1989). The impact of research and development on productivity growth. BLS Bulletin, 2331, 3-8.

Borensztein, E., De Gregorio, J., \& Lee, J.-W. (1998). How does foreign direct investment affect economic growth? Journal of International Economics, 45(1), 115-35.

Brambilla, I., Hale, G., \& Long, C. (2009). Foreign direct investment and the incentives to innovate and imitate. The Scandinavian Journal of Economics, 111(4), 835-61.

Coe, D., \& Helpman, E. (1995). International R\&D spillovers. European Economic Review, 39(5), 859-87.

Coe, D., Helpman, E., \& Hoffmaister, A. (1997). North-South R\&D spillovers. Economic Journal, 107(440), 134-49.

Coelli, T., Perelman, S., \& Romano, E. (1999). Accounting for environmental influences in stochastic frontier models: With application to international airlines. Journal of Productivity Analysis, 11(3), 251-273.

Coelli, T., Rao, D. S. P., O’Donnell, C. J., \& Battese, G. E. (2005) An introduction to efficiency and productivity analysis. New York, NY: Springer Science.

Cohen, W. M., \& Levinthal, D. A. (1989). Innovation and learning: The two faces of R\&D. Economic Journal, 99(397), 569-596.

Ding, L., Haynes, K., \& Liu, Y. (2008). Telecommunications infrastructure and regional income convergence in China: panel data approaches. Annals of Regional Science, 42(4), 843-861.

Dollar, D., \& Kraay, A. (2004). Trade, growth, and poverty. Economic Journal, 114(493), F22-F49.

Eaton, J., \& Kortum, S. (1996). Trade in ideas: Patenting and productivity in the OECD. Journal of International Economics, 40(3-4), 251-278.

Easterly, W., \& Levine, R. (2001). What have we learned from a decade of empirical research on growth? It's not factor accumulation: Stylized

World Development, Vol 40, No. 10 (October 2012): pg. 1982-1998. DOI. This article is @ Elsevier and permission has been granted for this version to appear in e-Publications@Marquette. Elsevier does not grant permission for this article to be further copied/distributed or hosted elsewhere without the express permission from Elsevier. 
facts and growth models. World Bank Economic Review, 15(2), 177219.

Fedderke, J., Perkins, P., \& Luiz, J. (2006). Infrastructural investment in longrun economic growth: South Africa 1875-2001. World Development, 34(6), 1037-1059.

Findlay, R. (1978). Relative backwardness, direct foreign investment, and the transfer of technology: A simple dynamic model. Quarterly Journal of Economics, 92(1), 1-16.

Fraga, A. (2004). Latin America since the 1990s: Rising from the sickbed? Journal of Economic Perspectives, 18(2), 89-106.

Girma, S., \& Gorg, H. (2007). The role of the efficiency gap for spillovers from FDI: Evidence from the UK electronics and engineering sectors. Open Economies Review, 18(2), 215-232.

Glass, A., \& Saggi, K. (1998). International technology transfer and the technology gap. Journal of Development Economics, 55(2), 369-398.

Grossman, G., \& Helpman, E. (1991). Innovation and Growth in the Global Economy. Cambridge and London, MA: MIT Press.

Guan, Z., Kumbhakar, S. C., Myers, R., \& Oude-Lansink, A. (2009). Excess capital and its implications in econometric analysis of production. American Journal of Agricultural Economics, 91(3), 765-776.

Hejazi, W., \& Safarian, E. (1999). Trade, foreign direct investment and R\&D spillovers. Journal of International Business Studies, 30(3), 491-511.

Henry, M., Kneller, R., \& Milner, C. (2009). Trade, technology transfer and national efficiency in developing countries. European Economic Review, 53(2), 237-254.

Jayasuriya, R., \& Wodon, Q. (2005). Measuring and explaining the impact of productive efficiency on economic development. World Bank Economic Review, 19(1), 121-40.

Jorgenson, D., \& Griliches, Z. (1967). The explanation of productivity change. Review of Economic Studies, 34(3), 249-280.

Keller, W. (2004). International technology diffusion. Journal of Economic Literature, 42(3), 752-82.

Keller, W., \& Yeaple, S. R. (2009). Multinational enterprises, international trade, and productivity growth: Firm level evidence from the United States. The Review of Economics and Statistics, 91(4), 821-831.

Kendrick, J. (1961). Productivity trends in the United States. Princeton, N.J.: Princeton University Press.

Klein, P., \& Luu, H. (2003). Politics and productivity. Economic Inquiry, 41(3), 433-47.

Kneller, R., \& Stevens, P. (2003). The specification of the aggregate production function in the presence of inefficiency. Economics Letters, $81(2), 223-226$.

World Development, Vol 40, No. 10 (October 2012): pg. 1982-1998. DOI. This article is @ Elsevier and permission has been granted for this version to appear in e-Publications@Marquette. Elsevier does not grant permission for this article to be further copied/distributed or hosted elsewhere without the express permission from Elsevier. 
NOT THE PUBLISHED VERSION; this is the author's final, peer-reviewed manuscript. The published version may be

accessed by following the link in the citation at the bottom of the page.

Kneller, R., \& Stevens, P. (2006). Frontier technology and absorptive capacity: Evidence from OECD manufacturing industries. Oxford Bulletin of Economics and Statistics, 68(1), 1-21.

Koop, G., Osiewalski, J., \& Steel, M. F. J. (1999). The components of our growth: A stochastic frontier analysis. Oxford Bulletin of Economics and Statistics, 61(4), 455-487.

Kumbhakar, S., Ghosh, S., \& McGuckin, T. (1991). A generalized production frontier approach for estimating determinants of inefficiency in U.S. dairy farms. Journal of Business and Economic Statistics, 9(3), 279286.

Kumbhakar, S., \& Lovell, C. (2000). Stochastic frontier analysis. Cambridge, New York and Melbourne: Cambridge University Press.

Kumbhakar, S., \& Wang, H.-J. (2005). Estimation of growth convergence using a stochastic production frontier approach. Economics Letters, 88(3), 300-305.

Li, X., \& Liu, X. (2005). Foreign direct investment and economic growth: An increasingly endogenous relationship. World Development, 33(3), 393407.

Mastromarco, C. (2008). Foreign capital and efficiency in developing countries. Bulletin of Economic Research, 60(4), 351-374.

Mastromarco, C., \& Ghosh, S. (2009). Foreign capital, human capital, and efficiency: A stochastic frontier analysis for developing countries. World Development, 37(2), 489-502.

Meeusen, W., \& van den Broeck, J. (1977). Efficiency estimation from CobbDouglas production functions with composed error. International Economic Review, 18(2), 435-444.

Miller, S. M., \& Upadhyay, M. P. (2000) The effects of openness, trade orientation, and human capital on total factor productivity. Journal of Development Economics, 63(2), 399-423.

Nourzad, F. (2008). Openness and the efficiency of FDI: A panel stochastic production frontier study. International Advances in Economic Research, 14(1), 25-35.

Quigley, J. (1998). Urban diversity and economic growth. Journal of Economic Perspectives, 12(2), 127-138.

Rodrik, D. (1999). Where did all the growth go? External shocks, social conflict, and growth collapses. Journal of Economic Growth, 4(4), 385412.

Rodriguez, F., \& Rodrik, D. (1999). Trade policy and economic growth: A skeptic's guide to cross-national evidence. NBER Working Paper 7081, National Bureau of Economic Research.

Rodriguez-Clare, A. (1996). Multinationals, linkages and economic development. American Economic Review, 86(4), 852-873.

World Development, Vol 40, No. 10 (October 2012): pg. 1982-1998. DOI. This article is @ Elsevier and permission has been granted for this version to appear in e-Publications@Marquette. Elsevier does not grant permission for this article to be further copied/distributed or hosted elsewhere without the express permission from Elsevier. 
Roller, L.-H., \& Waverman, L. (2001). Telecommunications infrastructure and economic development: A simultaneous approach. American Economic Review, 91(4), 909-23.

Romer, P. M. (1990). Endogenous technological change. Journal of Political Economy, 98(5), S71-S102.

Sachs, J., \& Warner, A. (1999). The big push, natural resource booms and growth. Journal of Development Economics, 59(1), 43-76.

Senhadji, A. (2000). Sources of economic growth: An extensive growth accounting exercise. IMF Staff Papers, 47(1), 129-158

Skidmore, M., \& Toya, H. (2002). Do natural disasters promote long-run growth? Economic Inquiry, 40(4), 664-687.

Solow, R. (1957). Technical change and the aggregate production function. Review of Economics and Statistics, 39(3), 312-320.

Tallman, E., \& Wang, P. (1994). Human capital and endogenous growth: Evidence from Taiwan. Journal of Monetary Economics 34(1), 101-124.

Um, P., Straub, S., \& Vellutini, C. (2009). Infrastructure and economic growth in the Middle East and North Africa. Policy Research Working Paper Series 5105, World Bank.

United Nations Educational, Scientific and Cultural Organization. (2009). A global perspective on research and development. UIS Fact Sheet, No. 2.

van Pottelsberghe de la Potterie, B., \& Lichtenberg, F. (2001). Does foreign direct investment transfer technology across borders? Review of Economics and Statistics, 83(3), 490-97.

Vuong, Q. H. (1989). Likelihood ratio tests for model selection and nonnested hypotheses. Econometrica, 57(2), 307-333.

Wang, J. Y., \& Blomström, M. (1992). Foreign investment and technology transfer: A simple model. European Economic Review, 36(1), 137155.

Wijeweera, A., Villano, R., \& Dollery, B. (2010). Economic growth and FDI inflows: A stochastic frontier analysis. Journal of Developing Areas, 43(2), 143-158.

Xu, B., \& Wang, Jianmao (2000). Trade, FDI, and international technology diffusion. Journal of Economic Integration, 15(4), 585-601.

Young, A. (1991). Learning by doing and the dynamic effects of international trade. NBER Working Paper 3577, National Bureau of Economic Research.

Yousef, T. (2004). Development, growth and policy reform in the Middle East and North Africa since 1950. Journal of Economic Perspectives, 18(3), 91-115.

World Development, Vol 40, No. 10 (October 2012): pg. 1982-1998. DOI. This article is @ Elsevier and permission has been granted for this version to appear in e-Publications@Marquette. Elsevier does not grant permission for this article to be further copied/distributed or hosted elsewhere without the express permission from Elsevier. 
NOT THE PUBLISHED VERSION; this is the author's final, peer-reviewed manuscript. The published version may be accessed by following the link in the citation at the bottom of the page.

Table 1. Descriptive statistics

\begin{tabular}{llllll}
\hline Variable & No. of Obs. & Mean & Std. Dev. & Min & Max \\
\hline$Y$ (in million) & 1622 & 359613.6 & 1153633 & 259.42 & $1.15 \mathrm{E}+07$ \\
$K$ (in million) & 1622 & 739404 & 2299230 & 356.474 & $2.15 \mathrm{E}+07$ \\
$L$ (in million) & 1622 & 28.483 & 91.818 & 0.13 & 782.791 \\
SYR & 1622 & 1.888 & 1.289 & 0.056 & 5.687 \\
Enroll & 1688 & 64.92 & 34.53 & 3.67 & 161.66 \\
$R D^{F D I}$ & 1622 & 50544.22 & 124712.3 & 0 & 1132966 \\
$R D^{M}$ & 1622 & 51448.11 & 94323.95 & 88.585 & 617410.9 \\
$I N F R A$ & 1622 & 39.356 & 46.267 & 0.040 & 214.79 \\
OPEN (in unit) & 1622 & 0.74 & 0.51 & 0.12 & 4.57 \\
$U R B$ (in unit) & 1622 & 0.57 & 0.23 & 0.09 & 1 \\
$P S$ & 1622 & 67.215 & 14.712 & 27.333 & 96.083 \\
\hline
\end{tabular}

World Development, Vol 40, No. 10 (October 2012): pg. 1982-1998. DOI. This article is @ Elsevier and permission has been granted for this version to appear in e-Publications@Marquette. Elsevier does not grant permission for this article to be further copied/distributed or hosted elsewhere without the express permission from Elsevier. 
NOT THE PUBLISHED VERSION; this is the author's final, peer-reviewed manuscript. The published version may be accessed by following the link in the citation at the bottom of the page.

Table 2. Production function and technical inefficiency estimates

\begin{tabular}{|c|c|c|c|c|c|c|c|c|c|c|}
\hline \multicolumn{11}{|l|}{ Panel (a): production function } \\
\hline & \multicolumn{2}{|c|}{$\begin{array}{l}\text { R\&D with } 5 \% \text { Dep. } \\
\text { Rate } \\
\text { (1) }\end{array}$} & \multicolumn{2}{|c|}{$\begin{array}{l}\text { R\&D with } 10 \% \text { Dep. } \\
\text { Rate } \\
\text { (2) }\end{array}$} & \multicolumn{2}{|c|}{$\begin{array}{l}\text { R\&D with } 10 \% \text { Dep. } \\
\text { Rate and Enrollment } \\
\text { (3) }\end{array}$} & \multicolumn{2}{|c|}{$\begin{array}{l}\text { R\&D with } 10 \% \text { Dep. } \\
\text { Rate (Effective Labor) } \\
\text { (4) }\end{array}$} & \multicolumn{2}{|c|}{$\begin{array}{l}\text { R\&D with } 10 \% \text { Dep. } \\
\text { Rate (Lagged Values) } \\
\text { (5) }\end{array}$} \\
\hline & Coefficient & Std. Err. & Coefficient & Std. Err. & Coefficient & Std. Err. & Coefficient & Std. Err. & Coefficient & Std. Err. \\
\hline $\ln K$ & $-0.237^{* * * *}$ & {$[0.084]$} & $-0.236^{* * *}$ & {$[0.084]$} & $-0.208^{* * *}$ & {$[0.060]$} & $-0.342^{* * *}$ & {$[0.075]$} & $-0.228^{* * *}$ & {$[0.085]$} \\
\hline $\ln L$ & $1.068^{* * *}$ & {$[0.095]$} & $1.066^{* * *}$ & {$[0.095]$} & $0.866 * * *$ & {$[0.066]$} & & & $1.065^{* * *}$ & {$[0.094]$} \\
\hline $\ln H$ & $0.69^{* * *}$ & {$[0.16]$} & $0.693 * * *$ & {$[0.158]$} & $0.55^{* * *}$ & {$[0.12]$} & & & $0.682 * * *$ & {$[0.161]$} \\
\hline $\ln (H \times L)$ & & & & & & & $0.975 * * *$ & {$[0.087]$} & & \\
\hline$(\ln K)^{2}$ & $0.0985^{* * *}$ & {$[0.0083]$} & $0.0984 * * *$ & {$[0.0083]$} & $0.0902^{* * *}$ & {$[0.0092]$} & $0.1064 * * *$ & {$[0.0076]$} & $0.0979 * * *$ & {$[0.0084]$} \\
\hline$(\ln L)^{2}$ & $0.082 * * *$ & {$[0.011]$} & $0.082^{* * *}$ & {$[0.011]$} & $0.052 * * *$ & {$[0.011]$} & & & $0.083 * * *$ & {$[0.011]$} \\
\hline$(\ln H)^{2}$ & 0.032 & {$[0.033]$} & 0.032 & {$[0.033]$} & -0.018 & {$[0.053]$} & & & 0.037 & {$[0.034]$} \\
\hline $\ln (H \times L)^{2}$ & & & & & & & $0.064 * * *$ & {$[0.011]$} & & \\
\hline $\ln K \times \ln L$ & $-0.0886^{* * * *}$ & {$[0.0094]$} & $-0.0884 * * *$ & {$[0.0094]$} & $-0.067 * * *$ & {$[0.010]$} & & & $-0.0887 * * *$ & {$[0.0093]$} \\
\hline $\ln K \times \ln H$ & $-0.061^{* * *}$ & {$[0.015]$} & $-0.061 * * *$ & {$[0.015]$} & -0.017 & {$[0.023]$} & & & $-0.061 * * *$ & {$[0.015]$} \\
\hline $\ln L \times \ln H$ & $0.093^{* * *}$ & {$[0.016]$} & $0.092^{* * *}$ & {$[0.016]$} & 0.028 & {$[0.023]$} & & & $0.093^{* * *}$ & {$[0.016]$} \\
\hline $\ln K \times \ln (H \times L)$ & & & & & & & $-0.0779^{* * *}$ & {$[0.0087]$} & & \\
\hline Year & $-0.069 * * *$ & {$[0.013]$} & $-0.069 * * *$ & {$[0.013]$} & $-0.0449 * * *$ & [0.0089] & $-0.066 * * *$ & {$[0.012]$} & $-0.071^{* * * *}$ & {$[0.013]$} \\
\hline Year Squared & $0.00044^{* *}$ & {$[0.00022]$} & $0.00044 * *$ & {$[0.00022]$} & $0.00046^{*}$ & {$[0.00025]$} & $0.00044^{* *}$ & {$[0.00022]$} & $0.00062 * *$ & {$[0.00024]$} \\
\hline Year $\times \ln L$ & $-0.0053^{* * *}$ & {$[0.0013]$} & $-0.0052^{* * *}$ & {$[0.0013]$} & $-0.0094 * * *$ & {$[0.0013]$} & & & $-0.0052^{* * *}$ & {$[0.0014]$} \\
\hline Year $\times \ln K$ & $0.0056 * * *$ & {$[0.0013]$} & $0.0056^{* * *}$ & {$[0.0013]$} & $0.0093^{* * *}$ & {$[0.0013]$} & $0.0052^{* * * *}$ & {$[0.0011]$} & $0.0055^{* * * *}$ & {$[0.0013]$} \\
\hline Year $\times \ln H$ & -0.0030 & {$[0.0018]$} & -0.0029 & {$[0.0018]$} & $-0.0153^{* * *}$ & {$[0.0028]$} & & & -0.0027 & {$[0.0019]$} \\
\hline Year $\times \ln (H \times L)$ & & & & & & & $-0.0043^{* * *}$ & {$[0.0012]$} & & \\
\hline Regional Dummies & YES & & YES & & YES & & YES & & YES & \\
\hline Constant & $7.14^{* * *}$ & {$[0.44]$} & $7.13^{* * *}$ & {$[0.44]$} & $5.91^{* * *}$ & {$[0.39]$} & $7.76^{* * * *}$ & {$[0.38]$} & $7.09^{* * *}$ & {$[0.45]$} \\
\hline \multicolumn{11}{|l|}{ Panel (b): Technical Inefficiency } \\
\hline $\ln (I N F R A)$ & $-0.115^{* * *}$ & {$[0.019]$} & $-0.114^{* * *}$ & {$[0.019]$} & $-0.121^{* * *}$ & {$[0.016]$} & $-0.105^{* * *}$ & {$[0.018]$} & $-0.11^{* * *}$ & {$[0.018]$} \\
\hline OPEN & $0.215^{* * *}$ & {$[0.035]$} & $0.216^{* * *}$ & {$[0.035]$} & $0.203^{* * *}$ & {$[0.032]$} & $0.215^{* * * *}$ & {$[0.033]$} & $0.224^{* * *}$ & {$[0.035]$} \\
\hline$U R B$ & $-0.450^{\text {*** }}$ & {$[0.088]$} & $-0.450^{* * *}$ & {$[0.088]$} & $-0.399 * * *$ & {$[0.072]$} & $-0.466^{* * *}$ & {$[0.086]$} & $-0.403 * * *$ & {$[0.090]$} \\
\hline $\ln (P S)$ & $-0.229^{* * *}$ & {$[0.071]$} & $-0.231^{* * *}$ & {$[0.071]$} & $-0.199 * * *$ & {$[0.053]$} & $-0.220^{* * *}$ & {$[0.072]$} & $-0.274 * * *$ & {$[0.074]$} \\
\hline $\ln R D^{F D I}$ & $-0.0120^{* *}$ & {$[0.0056]$} & $-0.0127 * *$ & {$[0.0059]$} & $0.058^{* * * *}$ & {$[0.019]$} & $-0.0148^{* *}$ & {$[0.0056]$} & & \\
\hline $\ln R D^{M}$ & $-0.140 * * *$ & {$[0.019]$} & $-0.138^{* * *}$ & {$[0.019]$} & $-0.238^{* * *}$ & {$[0.028]$} & $-0.157 * * *$ & {$[0.018]$} & & \\
\hline $\ln R D^{F D I} \times \ln H$ & $-0.0191^{* * * *}$ & {$[0.0061]$} & $-0.0211^{* * * *}$ & {$[0.0065]$} & -0.0159 *** & {$[0.0052]$} & $-0.0255^{* * *}$ & {$[0.0057]$} & & \\
\hline $\ln R D^{M} \times \ln H$ & $0.0315^{* * *}$ & {$[0.0082]$} & $0.0335^{* * *}$ & {$[0.0086]$} & $0.0240^{* * *}$ & {$[0.0073]$} & $0.0457 * * *$ & {$[0.0054]$} & & \\
\hline $\ln R D^{F D I}(t-1)$ & & & & & & & & & $-0.0135^{* *}$ & {$[0.0060]$} \\
\hline $\ln R D^{M}(t-1)$ & & & & & & & & & $-0.139 * * *$ & {$[0.019]$} \\
\hline $\ln R D^{F D l} \times \ln H(t-1)$ & & & & & & & & & $-0.0209^{* * *}$ & {$[0.0064]$} \\
\hline $\ln R D^{M} \times \ln H(t-1)$ & & & & & & & & & $0.0317^{* * *}$ & {$[0.0083]$} \\
\hline Constant & $2.660^{* * *}$ & [0.319] & $2.59^{* * *}$ & {$[0.31]$} & $2.67^{* * *}$ & {$[0.23]$} & $2.68^{* * *}$ & {$[0.31]$} & $2.74 * * *$ & {$[0.33]$} \\
\hline Mean Efficiency & 0.78 & & 0.78 & & 0.72 & & 0.78 & & 0.79 & \\
\hline Gamma & 0.90 & & 0.90 & & 0.86 & & 0.91 & & 0.90 & \\
\hline Log Liklihood & 565.82 & & 566.63 & & 508.17 & & 548.90 & & 551.10 & \\
\hline Observations & 1622 & & 1622 & & 1688 & & 1622 & & 1545 & \\
\hline \multicolumn{11}{|c|}{ Panel C. likelihood ratio tests on model specifications } \\
\hline $\mathrm{H}_{0}$ : Cobb-Douglas Specification & $326.25^{* * *}$ & & $325.29 * * *$ & & $450.50^{* * *}$ & & $308.23^{* * *}$ & & $307.00^{* * *}$ & \\
\hline $\mathrm{H}_{0}$ : Neutral Technological Change & $39.08^{* * *}$ & & $38.94 * * *$ & & $58.23 * * *$ & & $32.15 * * *$ & & $36.84 * * *$ & \\
\hline $\mathrm{H}_{0}: \gamma=\delta_{0}=\ldots=\delta_{8}=0$ & $796.51 * * *$ & & $798.14^{* * * *}$ & & $792.41^{* * * *}$ & & $818.26^{* * *}$ & & $767.08^{* * * *}$ & \\
\hline $\mathrm{H}_{0}: \delta_{1}=\ldots=\delta_{8}=0$ & $629.84 * * *$ & & $631.46 * * *$ & & $723.84 * * *$ & & $632.21 * * *$ & & $600.40 * * *$ & \\
\hline
\end{tabular}

World Development, Vol 40, No. 10 (October 2012): pg. 1982-1998. DOI. This article is C Elsevier and permission has been granted for this version to appear in e-Publications@Marquette. Elsevier does not grant permission for this article to be further copied/distributed or hosted elsewhere without the express permission from Elsevier. 
NOT THE PUBLISHED VERSION; this is the author's final, peer-reviewed manuscript. The published version may be accessed by following the link in the citation at the bottom of the page.

\begin{tabular}{|c|c|c|c|c|c|c|c|}
\hline & & $1986-89$ & $1990-94$ & $1995-99$ & $2000-04$ & $2005-07$ & $1986-2007^{\mathrm{a}}$ \\
\hline \multirow[t]{6}{*}{ All Countries } & & 0.7495 & 0.7576 & 0.7801 & 0.8013 & 0.8284 & 0.7798 \\
\hline & & {$[0.195]$} & {$[0.198]$} & {$[0.183]$} & {$[0.171]$} & {$[0.163]$} & {$[0.179]$} \\
\hline & Most Efficient Country & UK & UK & UK & UK & UK & UK \\
\hline & & 0.9783 & 0.9750 & 0.9769 & 0.9758 & 0.9722 & 0.9758 \\
\hline & Least Efficient Country & Malawi & Guyana & Guyana & Guyana & Guyana & Guyana \\
\hline & & 0.2655 & 0.2347 & 0.2942 & 0.3293 & 0.3496 & 0.2937 \\
\hline \multirow[t]{6}{*}{ OECD20 } & & 0.9091 & 0.9085 & 0.9181 & 0.9172 & 0.9068 & 0.9126 \\
\hline & & {$[0.047]$} & {$[0.052]$} & {$[0.051]$} & {$[0.056]$} & {$[0.058]$} & {$[0.046]$} \\
\hline & Most Efficient Country & UK & UK & UK & UK & UK & UK \\
\hline & & 0.9783 & 0.9750 & 0.9769 & 0.9758 & 0.9722 & 0.9758 \\
\hline & Least Efficient Country & Finland & Finland & Japan & Japan & Japan & Japan \\
\hline & & 0.8180 & 0.7607 & 0.7638 & 0.7315 & 0.7393 & 0.7839 \\
\hline \multirow{2}{*}{\multicolumn{2}{|c|}{ Sub-Saharan Africa }} & 0.5553 & 0.5511 & 0.5631 & 0.6048 & 0.6419 & 0.5764 \\
\hline & & {$[0.210]$} & {$[0.207]$} & {$[0.163]$} & {$[0.168]$} & {$[0.177]$} & {$[0.174]$} \\
\hline & Most Efficient Country & South Africa & South Africa & South Africa & South Africa & South Africa & South Africa \\
\hline & & 0.9345 & 0.9354 & 0.8959 & 0.9279 & 0.9436 & 0.9257 \\
\hline & Least Efficient Country & Malawi & Togo & Togo & Congo & Zimbabwe & Togo \\
\hline & & 0.2655 & 0.2681 & 0.3613 & 0.3849 & 0.4123 & 0.3487 \\
\hline \multirow{2}{*}{\multicolumn{2}{|c|}{ Middle East and North Africa }} & 0.6940 & 0.7373 & 0.8036 & 0.8656 & 0.9096 & 0.7984 \\
\hline & & {$[0.098]$} & {$[0.075]$} & {$[0.075]$} & {$[0.051]$} & {$[0.041]$} & {$[0.057]$} \\
\hline & Most Efficient Country & Jordan & Iran & Egypt & Egypt & Egypt & Egypt \\
\hline & & 0.7833 & 0.8177 & 0.9111 & 0.9488 & 0.9628 & 0.8604 \\
\hline & Least Efficient Country & Syria & Syria & Jordan & Jordan & Syria & Syria \\
\hline & & 0.5032 & 0.6338 & 0.7102 & 0.8228 & 0.8450 & 0.7054 \\
\hline \multirow{2}{*}{\multicolumn{2}{|c|}{ Latin America and the Caribbean }} & 0.7484 & 0.7437 & 0.7621 & 0.7671 & 0.8075 & 0.7606 \\
\hline & & {$[0.187]$} & {$[0.221]$} & {$[0.209]$} & {$[0.191]$} & {$[0.185]$} & {$[0.201]$} \\
\hline & Most Efficient Country & Uruguay & Uruguay & Argentina & Brazil & Brazil & Uruguay \\
\hline & & 0.9582 & 0.9589 & 0.9563 & 0.9450 & 0.9644 & 0.9462 \\
\hline & Least Efficient Country & Nicaragua & Guyana & Guyana & Guyana & Guyana & Guyana \\
\hline & & 0.4082 & 0.2347 & 0.2942 & 0.3293 & 0.3496 & 0.2937 \\
\hline \multirow[t]{6}{*}{ Asia } & & 0.7151 & 0.7643 & 0.8165 & 0.8586 & 0.9128 & 0.8156 \\
\hline & & {$[0.176]$} & {$[0.151]$} & {$[0.103]$} & {$[0.090]$} & {$[0.066]$} & {$[0.114]$} \\
\hline & Most Efficient Country & Singapore & Malaysia & Hong Kong & Hong Kong & Pakistan & Hong Kong \\
\hline & & 0.9220 & 0.9362 & 0.9301 & 0.9351 & 0.9595 & 0.9409 \\
\hline & Least Efficient Country & Sri Lanka & Sri Lanka & Sri Lanka & Sri Lanka & Sri Lanka & Sri Lanka \\
\hline & & 0.3803 & 0.4560 & 0.5468 & 0.6063 & 0.7189 & 0.5329 \\
\hline
\end{tabular}

World Development, Vol 40, No. 10 (October 2012): pg. 1982-1998. DOI. This article is @ Elsevier and permission has been granted for this version to appear in e-Publications@Marquette. Elsevier does not grant permission for this article to be further copied/distributed or hosted elsewhere without the express permission from Elsevier. 
NOT THE PUBLISHED VERSION; this is the author's final, peer-reviewed manuscript. The published version may be accessed by following the link in the citation at the bottom of the page.

Table 4. Efficiency scores of individual LDCs, 1986-2007

\begin{tabular}{|c|c|c|c|c|c|c|c|c|c|c|}
\hline \multicolumn{11}{|c|}{ Panel (a): most efficient countries } \\
\hline \multirow[b]{2}{*}{ Rank } & \multicolumn{2}{|c|}{$1986-89$} & \multicolumn{2}{|c|}{$1990-94$} & \multicolumn{2}{|l|}{ 1995-99 } & \multicolumn{2}{|c|}{ 2000-04 } & \multicolumn{2}{|c|}{ 2005-07 } \\
\hline & Country & Score & Country & Score & Country & Score & Country & Score & Country & Score \\
\hline 1 & Uruguay & 0.9582 & Uruguay & 0.9589 & Argentina & 0.9563 & Egypt & 0.9488 & Brazil & 0.9644 \\
\hline 2 & Mexico & 0.9511 & Argentina & 0.9532 & Uruguay & 0.9528 & Turkey & 0.9454 & Turkey & 0.9639 \\
\hline 3 & Argentina & 0.9447 & Venezuela & 0.9509 & Guatemala & 0.9477 & Brazil & 0.9450 & Egypt & 0.9628 \\
\hline 4 & South Africa & 0.9345 & Mexico & 0.9419 & Turkey & 0.9404 & Guatemala & 0.9357 & Argentina & 0.9599 \\
\hline 5 & Turkey & 0.9242 & Turkey & 0.9391 & Venezuela & 0.9386 & Hong Kong & 0.9351 & Pakistan & 0.9595 \\
\hline 6 & Singapore & 0.9220 & Malaysia & 0.9362 & Chile & 0.9311 & Mexico & 0.9325 & Uruguay & 0.9594 \\
\hline 7 & Venezuela & 0.9119 & South Africa & 0.9354 & Hong Kong & 0.9301 & Korea & 0.9301 & Hong Kong & 0.9576 \\
\hline 8 & Guatemala & 0.9069 & Guatemala & 0.9319 & Mexico & 0.9281 & South Africa & 0.9279 & India & 0.9543 \\
\hline 9 & Malaysia & 0.9053 & Korea & 0.9271 & Brazil & 0.9252 & Greece & 0.9235 & Singapore & 0.9482 \\
\hline 10 & Korea & 0.9043 & Singapore & 0.9262 & Dominican Republic & 0.9171 & India & 0.9209 & Philippines & 0.9470 \\
\hline
\end{tabular}

\begin{tabular}{|c|c|c|c|c|c|c|c|c|c|c|}
\hline \multirow[b]{2}{*}{ Rank } & \multicolumn{2}{|c|}{$1986-89$} & \multicolumn{2}{|c|}{$1990-94$} & \multicolumn{2}{|c|}{$1995-99$} & \multicolumn{2}{|c|}{$2000-04$} & \multicolumn{2}{|c|}{ 2005-07 } \\
\hline & Country & Score & Country & Score & Country & Score & Country & Score & Country & Score \\
\hline 1 & Malawi & 0.2655 & Guyana & 0.2347 & Guyana & 0.2942 & Guyana & 0.3293 & Guyana & 0.3496 \\
\hline 2 & Togo & 0.2726 & Togo & 0.2681 & Togo & 0.3613 & Congo & 0.3849 & Zimbabwe & 0.4123 \\
\hline 3 & Sri Lanka & 0.3803 & Malawi & 0.2894 & Congo & 0.3913 & Togo & 0.4133 & Malawi & 0.4502 \\
\hline 4 & Ghana & 0.3834 & Nicaragua & 0.3788 & Malawi & 0.3927 & Ghana & 0.4353 & Togo & 0.4556 \\
\hline 5 & Gambia & 0.3907 & Cameroon & 0.4027 & Gambia & 0.4111 & Malawi & 0.4432 & Congo & 0.4587 \\
\hline 6 & Nicaragua & 0.4082 & Gambia & 0.4134 & Ghana & 0.4131 & Gambia & 0.4768 & Ghana & 0.4678 \\
\hline 7 & Ecuador & 0.4139 & Ghana & 0.4175 & Nicaragua & 0.4384 & Nicaragua & 0.4840 & Nicaragua & 0.5265 \\
\hline 8 & Mali & 0.4177 & Mali & 0.4369 & Ecuador & 0.4656 & Zimbabwe & 0.4934 & Gambia & 0.5415 \\
\hline 9 & Cameroon & 0.4492 & Ecuador & 0.4450 & Cameroon & 0.4712 & Ecuador & 0.5019 & Ecuador & 0.5624 \\
\hline 10 & China & 0.4910 & Sri Lanka & 0.4560 & Mali & 0.5185 & Paraguay & 0.5454 & Paraguay & 0.6163 \\
\hline
\end{tabular}

Table 5. Contribution of international $R \& D$ transfer to technical efficiency (in percent)

\begin{tabular}{|c|c|c|c|c|c|c|c|}
\hline & & 1986-89 & $1990-94$ & 1995-99 & $2000-04$ & $2005-07$ & $1986-2007$ \\
\hline \multicolumn{8}{|l|}{ All Countries } \\
\hline & Mean & 10.053 & 9.911 & 10.374 & 10.072 & 9.680 & 9.971 \\
\hline & Conf. Interval & $(3.61,16.49)$ & $(3.23,16.59)$ & $(3.46,17.29)$ & $(3.55,16.59)$ & $(2.62,16.74)$ & $(3.77,16.17)$ \\
\hline \multicolumn{8}{|c|}{ (20) } \\
\hline & Mean & 12.350 & 12.458 & 12.182 & 11.684 & 12.259 & 12.182 \\
\hline & Conf. Interval & $(4.76,19.93)$ & $(5.41,19.50)$ & $(4.02,20.34)$ & $(3.46,19.91)$ & $(4.21,20.31)$ & $(5.02,19.34)$ \\
\hline \multicolumn{8}{|c|}{ Sub-Saharan Africa } \\
\hline & Mean & 6.871 & 6.424 & 6.647 & 6.714 & 7.430 & 6.651 \\
\hline & Conf. Interval & $(3.34,10.40)$ & $(3.01,9.84)$ & $(1.49,11.80)$ & $(2.64,10.79)$ & $(3.33,11.53)$ & $(2.69,10.61)$ \\
\hline \multicolumn{8}{|c|}{ Middle East and North Africa } \\
\hline & Mean & 10.972 & 10.919 & 10.918 & 9.723 & 8.680 & 10.342 \\
\hline & Conf. Interval & $(8.04,13.90)$ & $(8.13,13.70)$ & $(8.80,13.03)$ & $(6.16,13.28)$ & $(3.09,14.27)$ & $(8.00,12.68)$ \\
\hline \multicolumn{8}{|c|}{ Latin America and the Caribbean } \\
\hline & Mean & 9.452 & 9.088 & 10.023 & 10.739 & 9.887 & 9.765 \\
\hline & Conf. Interval & $(4.54,14.36)$ & $(3.66,14.52)$ & $(5.45,14.59)$ & $(6.69,14.79)$ & $(4.24,15.53)$ & $(5.65,13.88)$ \\
\hline \multicolumn{8}{|l|}{ Asia } \\
\hline & Mean & 9.833 & 9.965 & 11.865 & 10.660 & 8.340 & 10.220 \\
\hline & Conf. Interval & $(4.93,14.74)$ & $(4.76,15.17)$ & $(6.61,17.12)$ & $(5.47,15.85)$ & $(2.14,14.54)$ & $(5.44,15.00)$ \\
\hline
\end{tabular}

World Development, Vol 40, No. 10 (October 2012): pg. 1982-1998. DOI. This article is C Elsevier and permission has been granted for this version to appear in e-Publications@Marquette. Elsevier does not grant permission for this article to be further copied/distributed or hosted elsewhere without the express permission from Elsevier. 
NOT THE PUBLISHED VERSION; this is the author's final, peer-reviewed manuscript. The published version may be accessed by following the link in the citation at the bottom of the page.

Table 6. Net technical efficiency and potential efficiency ratio

\begin{tabular}{|c|c|c|c|c|c|c|}
\hline Panel (a): net technical efficiency & $1986-89$ & 1990-94 & $1995-99$ & $2000-04$ & $2005-07$ & 1986-2007 \\
\hline All Countries & $0.7704[0.189]$ & $0.7791[0.191]$ & $0.8038[0.173]$ & $0.8254[0.160]$ & $0.8502[0.151]$ & $0.8024[0.170]$ \\
\hline OECD20 & $0.9199[0.039]$ & $0.9188[0.045]$ & $0.9270[0.046]$ & $0.9261[0.052]$ & $0.9172[0.053]$ & $0.9223[0.041]$ \\
\hline Sub-Saharan Africa & $0.5817[0.212]$ & $0.5820[0.210]$ & $0.6036[0.167]$ & $0.6472[0.166]$ & $0.6845[0.172]$ & $0.6133[0.175]$ \\
\hline Middle-East and North Africa & $0.7243[0.101]$ & $0.7717[0.070]$ & $0.8433[0.061]$ & $0.9001[0.035]$ & $0.9331[0.028]$ & $0.8318[0.048]$ \\
\hline Latin America and the Caribbean & $0.7745[0.178]$ & $0.7673[0.215]$ & $0.7862[0.201]$ & $0.7935[0.183]$ & $0.8296[0.175]$ & $0.7854[0.194]$ \\
\hline Asia & $0.7321[0.173]$ & $0.7818[0.144]$ & $0.8355[0.096]$ & $0.8765[0.080]$ & $0.9256[0.052]$ & $0.8325[0.106]$ \\
\hline \multicolumn{7}{|l|}{ Panel (b): potential efficiency ratio (PER) } \\
\hline All Countries & $1.0329[0.024]$ & $1.0343[0.027]$ & $1.0367[0.031]$ & $1.0359[0.031]$ & $1.0318[0.031]$ & $1.0350[0.028]$ \\
\hline OECD20 & $1.0124[0.012]$ & $1.0119[0.012]$ & $1.0100[0.008]$ & $1.0101[0.008]$ & $1.0118[0.009]$ & $1.0111[0.009]$ \\
\hline Sub-Saharan Africa & $1.0526[0.021]$ & $1.0611[0.023]$ & $1.0752[0.021]$ & $1.0754[0.025]$ & $1.0725[0.028]$ & $1.0688[0.022]$ \\
\hline Middle-East and North Africa & $1.0446[0.016]$ & $1.0480[0.018]$ & $1.0512[0.023]$ & $1.0411[0.021]$ & $1.0265[0.017]$ & $1.0435[0.018]$ \\
\hline Latin America and the Caribbean & $1.0406[0.027]$ & $1.0388[0.028]$ & $1.0387[0.030]$ & $1.0404[0.027]$ & $1.0330[0.029]$ & $1.0393[0.028]$ \\
\hline Asia & $1.0270[0.021]$ & $1.0262[0.023]$ & $1.0254[0.022]$ & $1.0228[0.022]$ & $1.0155[0.022]$ & $1.0233[0.021]$ \\
\hline \multicolumn{7}{|l|}{ Panel (c): FDI-transferred R\&D PER } \\
\hline All Countries & $1.0374[0.022]$ & $1.0332[0.022]$ & $1.0327[0.023]$ & $1.0285[0.021]$ & $1.0234[0.021]$ & $1.0313[0.021]$ \\
\hline OECD20 & $1.0118[0.008]$ & $1.0093[0.007]$ & $1.0085[0.006]$ & $1.0072[0.007]$ & $1.0076[0.007]$ & $1.0089[0.006]$ \\
\hline Sub-Saharan Africa & $1.0563[0.014]$ & $1.0548[0.013]$ & $1.0587[0.012]$ & $1.0538[0.015]$ & $1.0499[0.017]$ & $1.0550[0.013]$ \\
\hline Middle-East and North Africa & $1.0561[0.004]$ & $1.0500[0.004]$ & $1.0440[0.013]$ & $1.0313[0.013]$ & $1.0183[0.010]$ & $1.0409[0.008]$ \\
\hline Latin America and the Caribbean & $1.0411[0.019]$ & $1.0348[0.019]$ & $1.0343[0.020]$ & $1.0324[0.016]$ & $1.0258[0.018]$ & $1.0339[0.017]$ \\
\hline Asia & $1.0437[0.018]$ & $1.0366[0.018]$ & $1.0327[0.017]$ & $1.0249[0.015]$ & $1.0141[0.013]$ & $1.0300[0.016]$ \\
\hline \multicolumn{7}{|l|}{ Panel (d): import-transferred $R \& D$ PER } \\
\hline All Countries & $1.0280[0.019]$ & $1.0292[0.020]$ & $1.0315[0.023]$ & $1.0302[0.022]$ & $1.0275[0.023]$ & $1.0299[0.021]$ \\
\hline OECD20 & $1.0208[0.016]$ & $1.0202[0.015]$ & $1.0173[0.013]$ & $1.0165[0.011]$ & $1.0192[0.012]$ & $1.0187[0.012]$ \\
\hline Sub-Saharan Africa & $1.0374[0.018]$ & $1.0429[0.020]$ & $1.0555[0.019]$ & $1.0541[0.022]$ & $1.0519[0.024]$ & $1.0497[0.020]$ \\
\hline Middle-East and North Africa & $1.0324[0.017]$ & $1.0358[0.018]$ & $1.0413[0.020]$ & $1.0343[0.019]$ & $1.0243[0.015]$ & $1.0345[0.016]$ \\
\hline Latin America and the Caribbean & $1.0325[0.022]$ & $1.0318[0.023]$ & $1.0311[0.025]$ & $1.0325[0.023]$ & $1.0269[0.024]$ & $1.0320[0.023]$ \\
\hline Asia & $1.0207[0.019]$ & $1.0209[0.018]$ & $1.0237[0.016]$ & $1.0205[0.017]$ & $1.0147[0.019]$ & $1.0203[0.017]$ \\
\hline
\end{tabular}

Note: Net technical efficiency is calculated by replacing " $\Sigma_{\mathrm{n}=5}^{8} \delta_{\mathrm{n}} \mathrm{z}_{\mathrm{n}, \mathrm{it}}$ " with the minimum of " $\Sigma_{\mathrm{n}=5}^{8} \delta_{\mathrm{n}} \mathrm{z}_{\mathrm{n}, \mathrm{it}}$ " in equation (12). Potential efficiency ratio (PER) is defined as the average of the net technical efficiency divided by the gross technical efficiency. Standard deviations are in parentheses.

World Development, Vol 40, No. 10 (October 2012): pg. 1982-1998. DOI. This article is (C) Elsevier and permission has been granted for this version to appear in e-Publications@Marquette. Elsevier does not grant permission for this article to be further copied/distributed or hosted elsewhere without the express permission from Elsevier. 
NOT THE PUBLISHED VERSION; this is the author's final, peer-reviewed manuscript. The published version may be accessed by following the link in the citation at the bottom of the page.
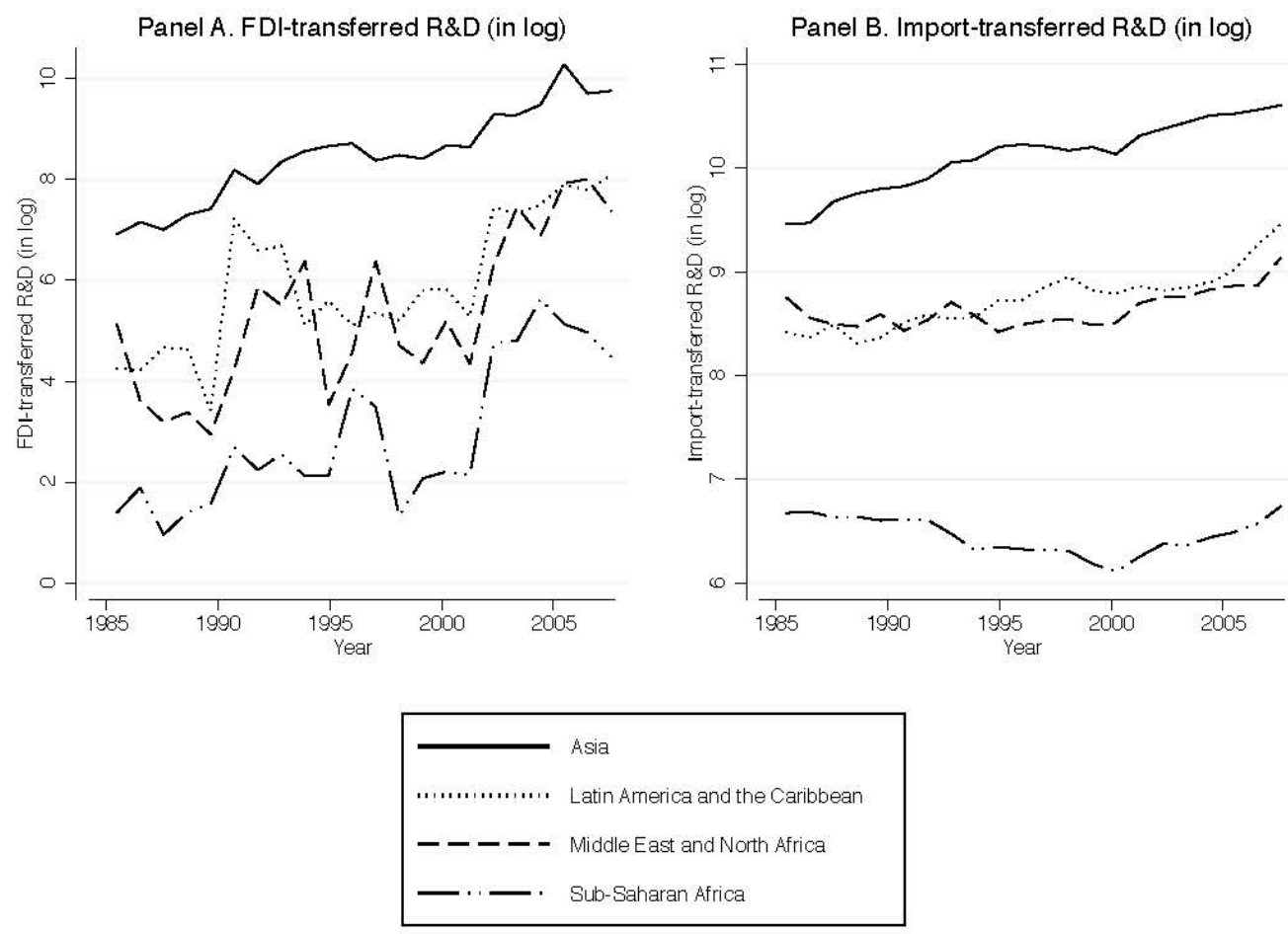

Figure 1. International $R \& D$ transfer
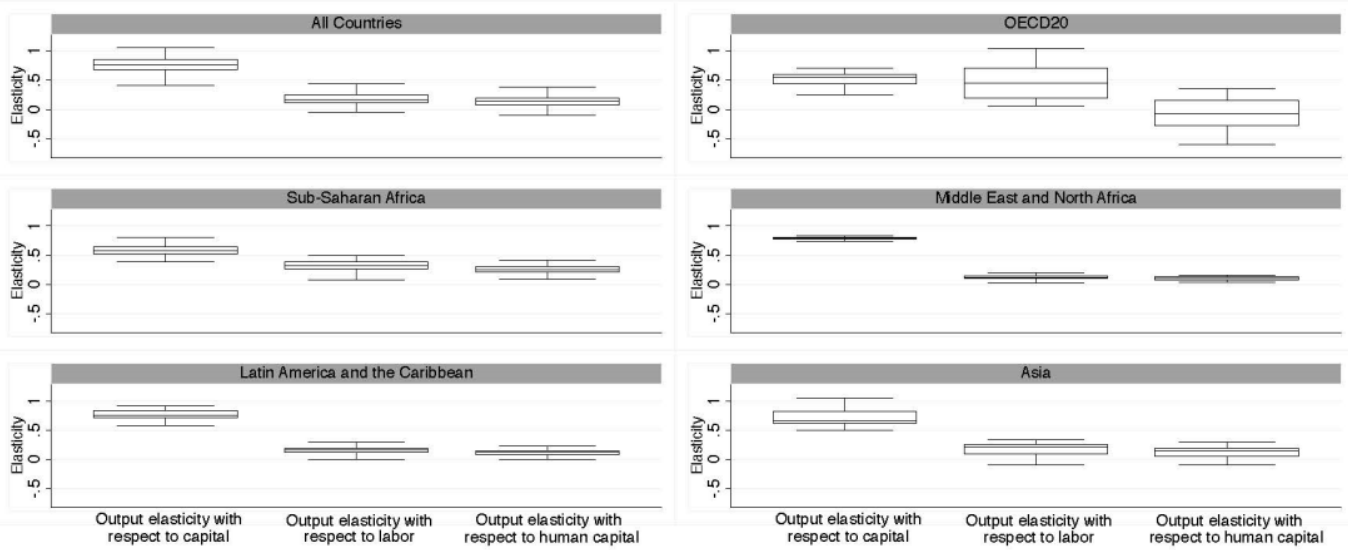

Figure 2. Output elasticities with respect to factors of production

World Development, Vol 40, No. 10 (October 2012): pg. 1982-1998. DOI. This article is C Elsevier and permission has been granted for this version to appear in e-Publications@Marquette. Elsevier does not grant permission for this article to be further copied/distributed or hosted elsewhere without the express permission from Elsevier. 
NOT THE PUBLISHED VERSION; this is the author's final, peer-reviewed manuscript. The published version may be accessed by following the link in the citation at the bottom of the page.
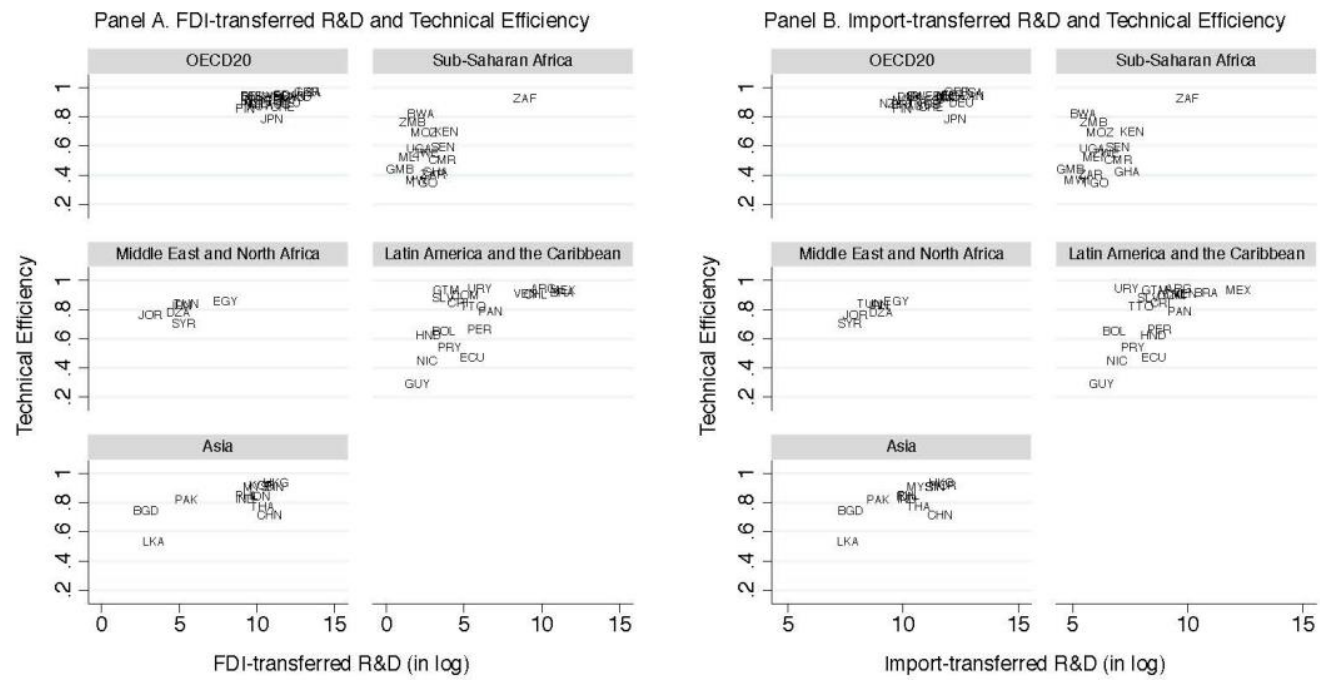

Figure 3. Technical efficiency and international $R \& D$ transfer
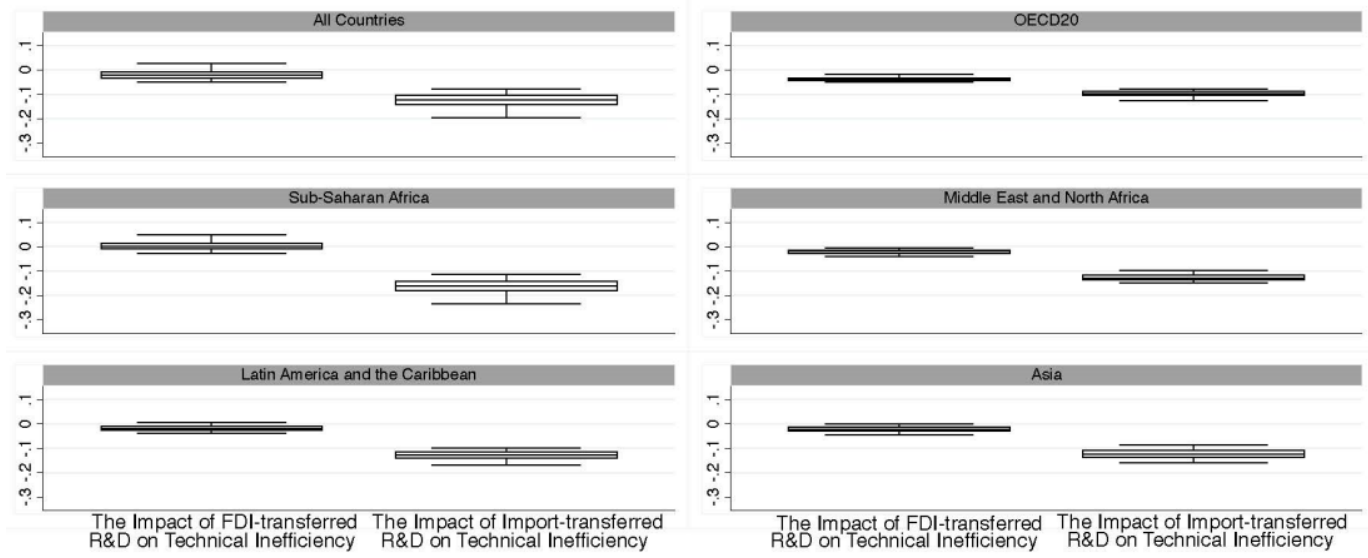

Figure 4. Distributions of the impact of foreign R\&D transferred through FDI and Imports on technical inefficiency

World Development, Vol 40, No. 10 (October 2012): pg. 1982-1998. DOI. This article is @ Elsevier and permission has been granted for this version to appear in e-Publications@Marquette. Elsevier does not grant permission for this article to be further copied/distributed or hosted elsewhere without the express permission from Elsevier. 
NOT THE PUBLISHED VERSION; this is the author's final, peer-reviewed manuscript. The published version may be accessed by following the link in the citation at the bottom of the page.

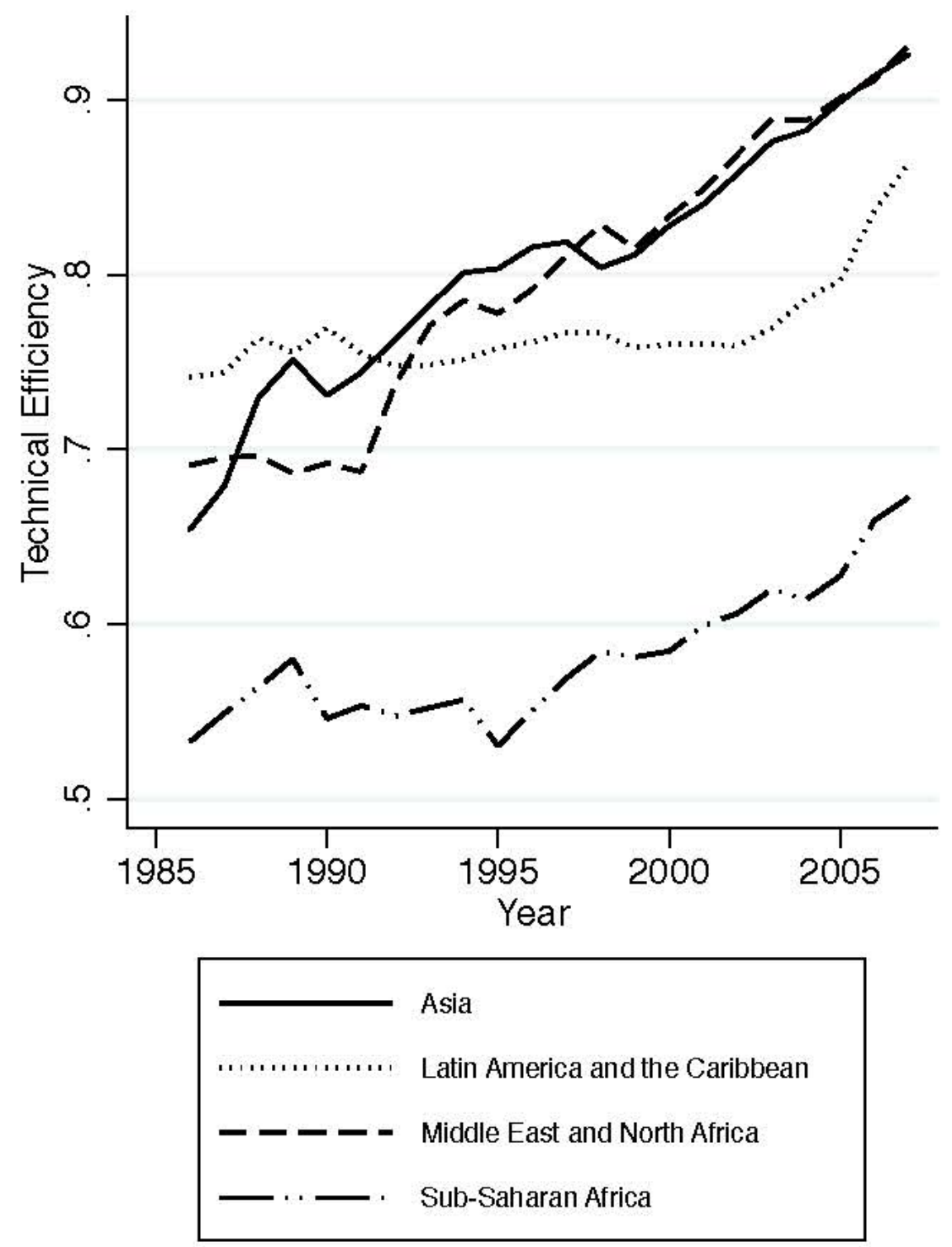

Figure 5. Technical efficiency over time

World Development, Vol 40, No. 10 (October 2012): pg. 1982-1998. DOI. This article is @ Elsevier and permission has been granted for this version to appear in e-Publications@Marquette. Elsevier does not grant permission for this article to be further copied/distributed or hosted elsewhere without the express permission from Elsevier. 
NOT THE PUBLISHED VERSION; this is the author's final, peer-reviewed manuscript. The published version may be accessed by following the link in the citation at the bottom of the page.

APPENDIX A

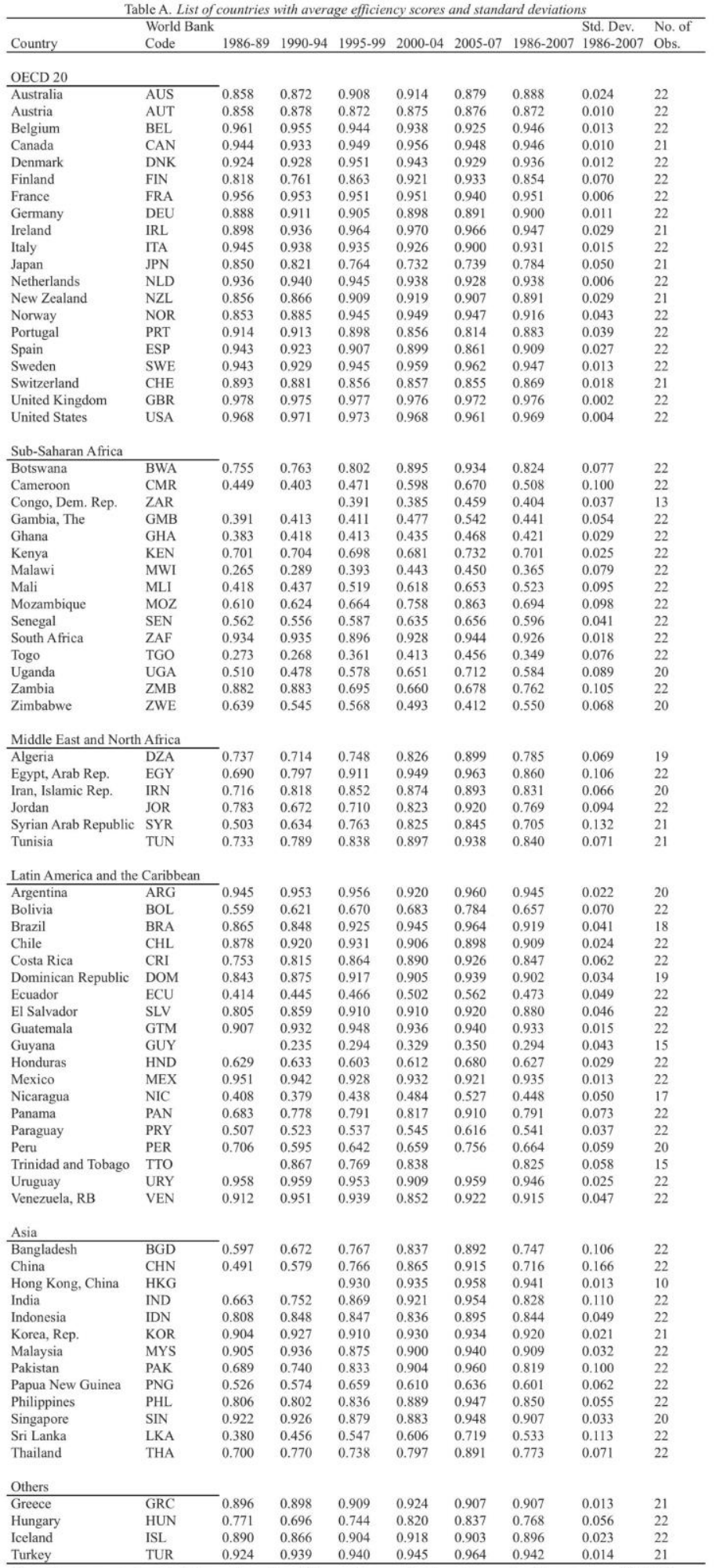

Note: The mean, standard deviation, and number of observations are for the entire sample. Others are non-OECD20

countries.

World Development, Vol 40, No. 10 (October 2012): pg. 1982-1998. DOI. This article is @ Elsevier and permission has been granted for this version to appear in e-Publications@Marquette. Elsevier does not grant permission for this article to be further copied/distributed or hosted elsewhere without the express permission from Elsevier. 